\title{
Mineral Inactivation of Zinc in Polluted Soil-Sustainability of Zeolite, Bentonite and Blends
}

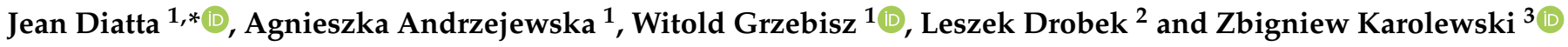 \\ 1 Department of Agricultural Chemistry and Environmental Biogeochemistry, \\ Poznan University of Life Sciences, 60-625 Poznan, Poland; agnieszka.andrzejewska11@gmail.com (A.A.); \\ witold.grzebisz@up.poznan.pl (W.G.) \\ 2 Department of Environment Monitoring, Central Mining Institute, 40-166 Katowice, Poland; 1.drobek@gig.eu \\ 3 Department of Phytopathology, Seed Science and Technology, Poznan University of Life Sciences, \\ 60-594 Poznan, Poland; zbigniew.karolewski@up.poznan.pl \\ * Correspondence: jean.diatta@up.poznan.pl
}

Citation: Diatta, J.; Andrzejewska, A.; Grzebisz, W.; Drobek, L.;

Karolewski, Z. Mineral Inactivation of Zinc in Polluted Soil—Sustainability of Zeolite, Bentonite and Blends. Minerals 2021, 11, 738. https://doi.org/ $10.3390 / \min 11070738$

Academic Editors: Anna Karczewska and Karolina Lewińska

Received: 30 May 2021

Accepted: 2 July 2021

Published: 7 July 2021

Publisher's Note: MDPI stays neutral with regard to jurisdictional claims in published maps and institutional affiliations.

Copyright: (c) 2021 by the authors. Licensee MDPI, Basel, Switzerland. This article is an open access article distributed under the terms and conditions of the Creative Commons Attribution (CC BY) license (https:// creativecommons.org/licenses/by/ $4.0 /)$.

\begin{abstract}
The study outlines a novel and traceable procedure for inactivating zinc polluted soil (an Anthrosols) adjacent to a former zinc (Zn) ore mine "Orzel Biały" in Bytom (Poland), where the total content of $\mathrm{Zn}$ amounted to $3988.0 \mathrm{mg} \mathrm{kg}^{-1}$. This pollution level initiated an inactivation process involving two natural mineral sorbents, i.e., zeolite $(Z)$ and bentonite $(B)$, as well as their five blends (ZeoBen) expressed as ZB: (1) ZB15/85, (2) ZB30/70, (3) ZB50/50, (4) ZB70/30 and (5) ZB85/15. Next, phosphorus $(\mathrm{P})$ as triple superphosphate (TSP, $46 \% \mathrm{P}_{2} \mathrm{O}_{5}$ ) was added to individual $\mathrm{ZB}$ at rates: $0.25 \%$, $0.5 \%, 1.0 \%$ and $2.0 \%$. All sorbents were added to the $\mathrm{Zn}$ polluted soil at $0 \%, 0.25 \%, 0.5 \%, 1.0 \%$ and $2.0 \%$ (dry weight basis). Treatments (1.0 kg of Zn-polluted soil with $Z B$ sorbents) were aged for 115 days. Data revealed that $Z B 85 / 15$ with prevailing zeolite caused a $Z n_{\text {act }}$ inactivation of $66-71 \%$, while zeolite induced $54 \%$ and $47 \%$ for bentonite. Reactive zinc $\left(Z n_{\text {reac }}\right)$ decreased much more $(20 \%)$ when zeolite was incorporated at the rate $2.5 \mathrm{~g} \cdot \mathrm{kg}^{-1}$ soil, and bentonite was $(10 \%)$ at the same rate. The application of the sorbent ZB50/50 enriched with triple superphosphate (TSP) raised the stabilization degree for both $\mathrm{Zn}$ fractions. The efficiency was significant at the TSP rate of $2.0 \%$ of the sorbent and at least the sorbent $+\mathrm{TSP}$ of $10 \mathrm{~g} \cdot \mathrm{kg}^{-1}$ soil. The cation exchange capacity (CEC) of about $2 \mathrm{cmol}_{(+)} \cdot \mathrm{kg}^{-1}$ controlled the activity $-0.50 \mathrm{mmol} \cdot \mathrm{dm}^{-3}$ of either $\gamma Z n_{\text {reac }}$ or $\gamma Z n_{\text {act }}$, hence a very low zinc ionic activity. The use of mineral blends with higher sharing of zeolite is promising for remediating metal-polluted lands in the case of zinc.
\end{abstract}

Keywords: soil; zeolite; bentonite; mineral blends; Zn pollution; inactivation; stabilisation; remediation; $\mathrm{Zn}$ activities; phosphate

\section{Introduction}

In natural conditions, soils have shaped physical as well as chemical properties that act efficiently in the mitigation of harmful changes induced by an excess of polluting substances such as trace metals. According to the United States Environmental Protection Agency (USEPA) [1], natural attenuation is the "use of natural processes to contain the spread of the contamination from chemical spills and reduce the concentration and amount of pollutants at contaminated sites". It can also be termed as intrinsic remediation, bioattenuation and intrinsic bioremediation. In this case, the contaminants are left on site and the naturally occurring processes are left to clean up the site [2]. Although natural attenuation may be used at numerous sites, it rarely can be used as a sole treatment process [3].

In many cases, anthropogenic pollutions exceed the neutralization as well as inactivation capacities of natural soils, where processes may be running on a long-term time scale. This creates immediate exposure risks to the environment and to humans. Hence the necessity to incorporate mineral additives, particularly natural, for mitigating the toxicity of the trace metals [4]. Basically, these practices do not reduce the total concentrations of 
$\mathrm{Zn}$ in the soil, but may efficiently limit the ecological risk related to transport or dispersion in the environment [5]. Separately, clay minerals, zeolite and bentonite have become the most used additives, and also phosphates are used [6-8].

Zeolites are characterized by the following high adsorption, ionic exchange and selectivity capacity [9]. For chabasite, the ionic selectivity order is assumed as $\mathrm{Pb}>\mathrm{Cu}$ $>\mathrm{Cd}>\mathrm{Zn}>\mathrm{Cr}>\mathrm{Co}>\mathrm{Ni}$, and for clinoptilolite it may bear the pattern $\mathrm{Pb}^{2+}>\mathrm{Fe}^{3+}$ $>\mathrm{Cr}^{3+} \geq \mathrm{Cu}^{2+}[10-12]$. Natural, as well as synthetic zeolites, strongly bind trace metals and this process appears much more competitive compared to plant roots [13]. Bentonites consist of at least $75 \%$ montmorillonite as a component of smectite [14], and is also characterized by developed sorption and retention properties of pollutants in soils [15-17]. The incorporation into soils of both minerals may alter their $\mathrm{pH}$, inducing a decrease of trace metals activity-Zn among others.

Phosphates are also being applied to inactivate $\mathrm{Zn}$ in polluted soils [18] and the highest rates may strengthen the stabilization effect of pollutants [19-21]. According to Corami [22], the efficiency of phosphate addition becomes low in case of high levels of trace metal pollution. If phosphates react chemically to form stable metal-P precipitates, it should be outlined that they (phosphates) are crucially important as nutrients for plants, basically in controlling rooting dynamics under such unfriendly soil conditions [23].

The frequent mineral remediation of polluted soils practiced up to date was focused on the application of single (individual) clay minerals, i.e., either zeolite or bentonite, and possibly with the incorporation of phosphates solely as ground phosphate rocks. However, these procedures do not fully exploit the neutralizing and inactivation capacities of the minerals towards pollutants. The concept elaborated in the current research was based on formulating zeolite and bentonite-based blends supplemented with phosphates.

A two-step proceeding was elaborated for the current mineral inactivation trial. First, it was assumed that the incorporation of both zeolite and bentonite, as well as their blends, into the $\mathrm{Zn}$ polluted soil would decrease the concentrations of water-soluble $\mathrm{Zn}$ fractions ( $\mathrm{Zn}_{\text {act }}$-active $\mathrm{Zn}$ forms) and simultaneously the $0.11 \mathrm{~mol} \mathrm{CH}_{3} \mathrm{COOH} \mathrm{dm}{ }^{-3}, \mathrm{pH} 3.0$ [24], expressed as reactive fractions ( $Z n_{\text {reac }}$-reactive $\mathrm{Zn}$ forms). Next, alteration of soil $\mathrm{pH}$ should shift zinc ions $\left(\mathrm{Zn}^{2+}\right)$ towards less mobility as $\mathrm{Zn}(\mathrm{OH})^{+}$or even $\mathrm{Zn}(\mathrm{OH})_{2}$. The second step involved the inclusion of phosphorus (P) as triple superphosphate (TSP, 46\% $\mathrm{P}_{2} \mathrm{O}_{5}$ ), which enables the blending of environmentally fully sustainable sorbents-additives addressed to metal-polluted grounds/sites.

\section{Materials and Methods}

The composite soil (about $200.0 \mathrm{~kg}$ ) was made of 50 single samples thoroughly mixed (10 sampling sites $\times 20$ single soil samples collected like a five on a dice with ca $20-50 \mathrm{~m}$ distance from the central point) and consisting of $20 \mathrm{~kg}$ per sample. They were collected from the area located at Bytom $\left(50^{\circ} 21^{\prime} 5^{\prime \prime} \mathrm{N} 18^{\circ} 58^{\prime} 10^{\prime \prime} \mathrm{E}\right)$ in the nearest vicinity of the $\mathrm{Zn}$ waste heap originating from the industrial processing of zinc ores (Figure 1). The soils at this location were the most impacted by the heap and were sampled at the depth of 0-25 cm. The composite soil was dried at ambient air temperature, next passed through a $2 \mathrm{~mm}$ mesh sieve and then stored safely for experimental use.

\subsection{Physical and Chemical Analysis of the Soil}

\subsubsection{Soil Properties}

Particles were determined by the methods described by Soil Survey Staff (2014), [25], where three fractions (sand, silt, clay) were separated. The soil was analyzed for $p H$ potentiometrically in an aqueous and 1 mole $\mathrm{KCl} \mathrm{dm}^{-3}$ solution at the ratio 1:2.5 [26]. The content of oxidizable organic carbon was assayed according to the method described by Wang et al. [27], whereas the effective cation exchange capacity $\left(C E C_{e f .}\right)$ was evaluated first by extracting $\mathrm{Ca}^{2+}, \mathrm{Mg}^{2+}, \mathrm{K}^{+}$and $\mathrm{Na}^{+}$with 1 mole $\mathrm{CH}_{3} \mathrm{COONH}_{4} \mathrm{dm}^{-3}$ (pH 7.0) and next summing these ions along with hydrolytic acidity [28]. Since processes related to $\mathrm{Zn}$ immobilization as well as inactivation could be expected as a result of the incorporation 
of mineral additives, therefore the soil used in the current study was assayed for the specific (total) surface area (SSA) by using the EGME (ethylene glycol monoethyl ether) method, $[29,30]$.

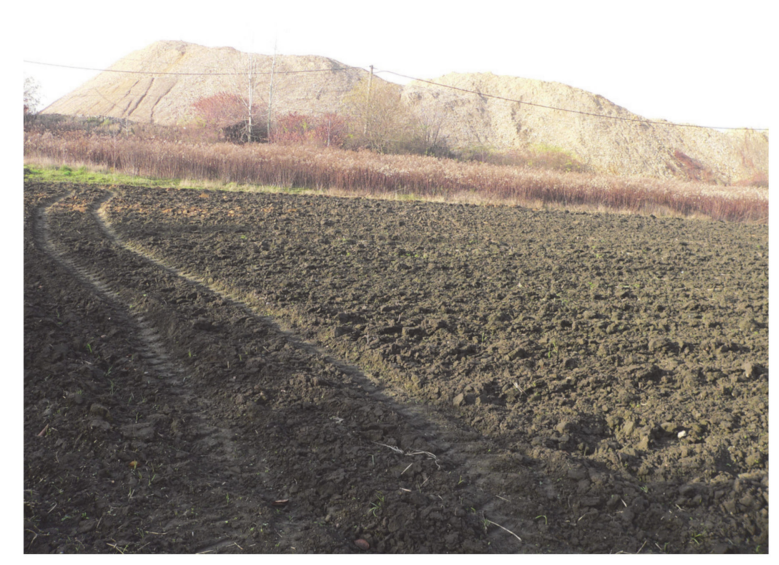

(A)

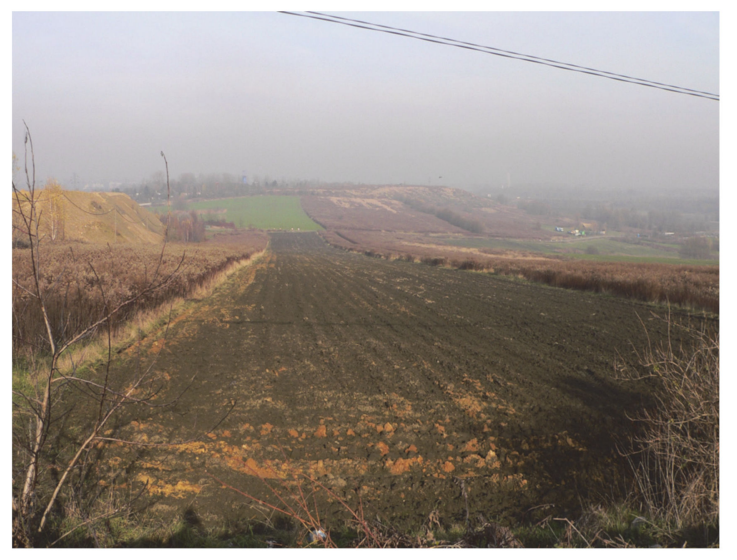

(B)

Figure 1. Sampling sites, (A) arable land neighboring the Zn-waste and (B): whole sampling zone (about $1000 \mathrm{~m}$ long).

\subsubsection{Determination of Zinc Content of the Soil Total Content}

The pseudo-total contents of $\mathrm{Zn}$ in the soils were assayed according to analytical procedures reported by Lebourg et al. [31] and Gupta et al. [32]. Some modifications have been incorporated, which consisted of using a 6 moles $\mathrm{HCl} \mathrm{dm}^{-3}$. Air-dried soil samples $(1.00 \pm 0.001 \mathrm{~g})$ were weighed into a glass Erlenmeyer flask and $15 \mathrm{~cm}^{3}$ of 6 moles $\mathrm{HCl}$ $\mathrm{dm}^{-3}$ were added. Next, the mixture was heated on a sand-bath at $140{ }^{\circ} \mathrm{C}$ for $2 \mathrm{~h}$ under reflux. After cooling, it was filtered through filter paper into $20 \mathrm{~cm}^{3}$ test tubes and filled up to the mark (i.e., $15 \mathrm{~cm}^{3}$ ) with double distilled water (DDW). The relevant concentrations reflected the total content of $\mathrm{Zn}$ in the soil $\left(\mathrm{Z} n_{t o t}\right)$.

\section{Reactive Forms of $\mathrm{Zn}$}

Soil samples $(5.00 \mathrm{~g})$ were weighed into $50 \mathrm{~cm}^{3}$ PE tubes and $20 \mathrm{~cm}^{3} 0.11$ mole $\mathrm{CH}_{3} \mathrm{COOH} \mathrm{dm}{ }^{-3}$, pH 3.0 added. The mixture was shaken on a rotating shaker $(120 \mathrm{rpm})$ for one hour, left to react for $2 \mathrm{~h}$ and next filtered through a filter paper into $25 \mathrm{~cm}^{3}$ test tubes. This test represents the first fraction of the 4-step BCR fractionation method [24] and is considered as potentially soluble, hence, it is expressed as reactive $\left(Z n_{\text {react }}\right)$.

\section{Water Soluble Forms of $\mathrm{Zn}$}

Aqueous forms of $\mathrm{Zn}$ were determined by using double distilled water (DDW) at a ratio of 1:5 (soil:DDW). Then, $5.0 \mathrm{~g}$ were weighed into $50 \mathrm{~cm}^{3} \mathrm{PE}$ tubes and $25 \mathrm{~cm}^{3}$ of DDW were added. The slurry was shaken for $1 \mathrm{~h}$, left to equilibrate for $24 \mathrm{~h}$ and then filtered through a filter paper into $25 \mathrm{~cm}^{3}$ test tubes. The extracted $\mathrm{Zn}$ fraction was expressed as active $\left(Z n_{a c t}\right)$. Next, the electrical conductivity $(E C)$ of the solution was determined conductively and according to the procedure reported by Hazelton and Murphy [28].

All extractions were performed in three replications. The concentrations of exchangeable $\mathrm{Ca}, \mathrm{Mg}$, $\mathrm{K}$ and $\mathrm{Na}$, as well as $\mathrm{Zn}$, were determined by flame atomic absorption spectrometry (FAAS), (Varian 250 Spectra plus). In the case of $\mathrm{Zn}$ assays, the relative standard deviation (RSD) was calculated from pooled data for applied methods. In the precision test, the average RSD (\%) for $\mathrm{Zn}$ in particular tests (i.e., total, reactive and active forms) ranged from $0.20 \%$ to $1.00 \%$. The accuracy of the total metal contents was determined using a reference material (Estuarine sediment 277 CRM certified by the Bureau Community of Reference (BCR), Brussels, Belgium). 


\subsection{Zeolite, Bentonite and Blends}

Two minerals, i.e., zeolite, bentonite and their five blends expressed as ZeoBen $(Z B)$, were used for the current study, as listed below:

(1) Zeolite (Z);

(2) Bentonite (B);

(3) ZeoBen $15 / 85$ (ZB15/85), i.e., $15 \% \mathrm{Z}$ to $85 \% \mathrm{~B}$, ( $\mathrm{m} / \mathrm{m}$ basis);

(4) ZeoBen 30/70 (ZB30/70);

(5) ZeoBen 50/50 (ZB50/50);

(6) ZeoBen 70/30 (ZB70/30);

(7) ZeoBen 85/15 (ZB85/15).

All $Z B$ sorbents were additionally treated with as triple superphosphate (TSP; $46 \% \mathrm{P}_{2} \mathrm{O}_{5}$ ) as a source of phosphorus $(\mathrm{P})$ at the rates: $0.25 \%, 0.50 \%, 1.0 \%$ and $2.0 \%$ corresponding to, $2.5,5,10$ and $20 \mathrm{~g}$ TSP per $1 \mathrm{~kg}$ of ZB sorbents, respectively.

All these sorbents, i.e., $Z, B, Z B 15 / 85, Z B 30 / 70, Z B 50 / 50, Z B 70 / 30$ and $Z B 85 / 15$ were tested in detail according to the procedures reported above and additionally for the external surface area $\left(\mathrm{SSA}_{\mathrm{BET}}\right.$ ) by using $\mathrm{N}_{2}$ at $77.35 \mathrm{~K}$ (Micromeritics ASAP 2010, Micromeritics Corporate Headquarters, 4356 Communications Drive. Norcross, GA 30093-2901, U.S.A) [33]. Next, the internal surface area $\left(S S A_{I N T}\right)$ was calculated by subtracting the external surface area $\left(S S A_{B E T}\right)$ from the specific (total) surface area $\left(S S A_{E G M E}\right)$ as listed below [30,34]:

$$
\begin{aligned}
& S S A_{E G M E}=S S A_{B E T}+S S A_{I N T} \\
& S S A_{I N T}=S S A_{E G M E}-S S A_{B E T}
\end{aligned}
$$

where

$S S A_{E G M E}$ - specific (total) surface area $\left(\mathrm{m}^{2} \cdot \mathrm{g}^{-1}\right)$,

$S S A_{B E T}$ - external surface area $\left(\mathrm{m}^{2} \cdot \mathrm{g}^{-1}\right)$,

$S S A_{I N T}$-internal surface area $\left(\mathrm{m}^{2} \cdot \mathrm{g}^{-1}\right)$.

\subsection{Experimental Design and Treatments}

To establish the trial, $1.0 \mathrm{~kg}$ of the composite $\mathrm{Zn}$-polluted soil was first weighed and all mineral sorbents, i.e., zeolite, bentonite and $Z B$ were added at the rates: $0.25 \%, 0.50 \%, 1.0 \%$ and 2.0\% (dry weight basis), respectively, to result in 2.5, 5.0, 10.0 and $20.0 \mathrm{~g}$ per one $\mathrm{kg}$ of Zn-polluted soil. In total, 87 treatments ( 7 sorbents $\times 4$ rates $\times 3$ replications) and three controls, i.e., with no sorbent addition have been elaborated. All treatments were aged for 115 days at a temperature of $22{ }^{\circ} \mathrm{C}\left( \pm 2{ }^{\circ} \mathrm{C}\right)$ and moisture level equivalent to field water holding capacity of $75 \%$.

The chemical tests are reported particularly in Section 2.1.2-Reactive forms of $\mathrm{Zn}$ $\left(Z n_{\text {reac }}\right)$ and Section 2.1.2-Water soluble forms of $Z n\left(Z n_{a c t}\right)$ which were performed for evaluating the process of inactivation. A specific approach based on Zn solution activity, as induced by the incorporation of sorbent, was also considered.

\section{Evaluation of Zinc Activity-Inactivation Status}

The mobility of $\mathrm{Zn}$ in the treatments may be evaluated in several ways, which are detailed in Section 2.1.2. In terms of geochemical processes, additional indices such as ionic activities play a key role in estimating the efficiency of mineral additives and the potential environmental response. A detailed model-based approach is displayed below [35]:

1 The extraction of zinc ions may be described:

$$
H_{x}^{+} \cdot S_{(s)}+Z n_{(a q)}^{2+} \Leftrightarrow H_{2-y} \cdot S Z n_{(s)}^{2+}+y H_{(a q)}^{+}
$$

where, $H_{x}^{+} \cdot S_{(s)}$ represents the protonated soil; aq expresses the soil solution (aqueous); $H_{2-y}$ are weakly bound alkaline ions. 
2 The expression of the equilibrium for point 1 is:

$$
K=\left[\frac{H_{x-y} S+Z n_{(s)}^{2+}}{H_{x} \cdot S_{(s)}}\right]^{\text {soil }}+\left[\frac{\alpha^{y} H^{+}}{\alpha Z n^{2+}}\right]^{\text {soil solution }}
$$

where, $\mathrm{K}$ is equilibrium constant.

3 In the case that the whole charges may be expressed by the cation exchange capacity $(C E C)$, therefore:

$$
C E C=\left(H_{x} \cdot S_{(s)}\right)+\left(H_{x-y} \cdot S \cdot Z n_{(s)}^{2+}\right)
$$

where, $C E C$ expresses cation exchange capacity.

4 If we consider $\Xi$, i.e., the fraction of charges occupied by $\mathrm{Zn}^{2+}$, to:

$$
\Xi=\frac{\left(H_{x-y} \cdot S \cdot Z n_{(s)}^{2+}\right)^{C Z n^{2+}}}{C E C} \times \frac{\text { cmolormmol }}{C E C(\text { cmolormmol })}
$$

5 Then:

$$
\frac{\Xi}{1-\Xi}=\left[\frac{H_{x-y} \cdot S \cdot Z n_{(s)}^{2+}}{H_{x} \cdot S_{(s)}}\right]
$$

6 In the current trial, the total $\mathrm{Zn}\left(\mathrm{Zn} n_{t o t}\right)$ content expressed as $\Xi_{0}$ was taken into consideration:

$$
\Xi_{0}=\frac{\left\{\mathrm{Zn}^{2+}\right\}^{\text {tot }}\left(\mathrm{mg} \cdot \mathrm{kg}^{-1}\right) \cdot 2(\mathrm{aq} / \mathrm{mol}) \cdot 1(\mathrm{kgsoil})}{\mathrm{CEC}\left(\mathrm{cmol} \cdot \mathrm{kg}^{-1} \cdot\{65.37\} \cdot 10(100 \mathrm{gsoil})\right)}
$$

Therefore,

$$
\Xi_{0}-\mathrm{Zn}^{2+}=\frac{\mathrm{Zn}^{2+}\left(\mathrm{mg} \cdot \mathrm{kg}^{-1}\right) \cdot 2(\mathrm{aq} / \mathrm{mol}) \cdot 1(\mathrm{kgsoil})}{\mathrm{CEC}\left(\mathrm{cmol} \cdot \mathrm{kg}^{-1} \cdot 65.37 \cdot 10(100 \mathrm{gsoil})\right)}
$$

where, numbers 2 and 10 represent the valence value and conversion into kilogram $(\mathrm{kg})$, respectively.

7 Since water extractable and $0.11{\text { mole } \mathrm{CH}_{3} \mathrm{COOH} \mathrm{dm}}^{-3}$ tests extract relatively low $\mathrm{Zn}$ pools, then for the equilibrium conditions with the tests, the relationship listed below appears as:

$$
\Xi=\Xi_{0}\left\{Z n^{\text {Zntot }}-\Xi_{\text {extrac. }}\left\{Z n^{\text {extrac. }}=\Xi_{0}-\frac{\{Z n\}^{\text {extrac. }}}{C E C} \cdot \frac{2}{\{65.37\} \cdot 10}\right\}\right\}
$$

8 The calculation of the activity coefficients for $\mathrm{Zn}$ was undertaken (for water at $25^{\circ} \mathrm{C}$ ) on the basis of the Debye-Hückel relationships:

$$
-\log \gamma\left\{Z n^{2+\text { extrac. }}=(0.509) \cdot\left(2^{2}\right) \sqrt{I}\right\}
$$

where, $\gamma=$ coefficient of activity and $I=$ ionic strength of the extractant (i.e., 0.11 mole $\mathrm{CH}_{3} \mathrm{COOH} \mathrm{dm}{ }^{-3}$.

9 Therefore, the relationship between the $\mathrm{Zn}$ solution concentration (in moles) versus its total content in the soil (in $\mathrm{kg}$ of soil) is expressed by:

$$
\left.\left\{\mathrm{Zn}^{2+}\right\}\left(\mathrm{mol} \cdot \mathrm{dm} \mathrm{m}^{-3}\right)=\mathrm{Zn}\right\}^{\mathrm{M}^{2+} \text { extrac. }}\left(\mathrm{mg} \cdot \mathrm{kg}^{-1}\right) \cdot \mathrm{Bm}
$$




$$
B m=\frac{0.040 \mathrm{kgsoil}}{\left(0.10 \mathrm{dm}^{3}\right) \cdot\{65.37\} \cdot\left(10^{3}\right)\left(\mathrm{mg} \cdot \mathrm{g}^{-1}\right)}
$$

where, $B m$ represents the distribution coefficient.

10 The equilibrium constant (as $\log K$ ) was estimated for $\mathrm{Zn}$ as below:

$$
\log K=\log _{10}\left[\frac{\Xi\left\{Z n^{\text {tot }}-\frac{\left\{\mathrm{Zn}^{2+}\right\}^{\text {extrac }}\left(\mathrm{mg} \cdot \mathrm{kg}^{-1}\right) \cdot 2}{\mathrm{CEC} \cdot\{65.37\} \cdot 10}\right\}}{1-\left\{\Sigma \Xi_{0}\left\{Z n^{\text {tot }}-\left\{\Sigma \Xi_{\text {extrac }}\left\{Z n^{2+}{ }^{\text {extrac }}\right\}\right\}\right\}\right\}}-p H_{\mathrm{H}_{2} \mathrm{O}}+2.04 \sqrt{I}-\log \left[\mathrm{Bm} \cdot \mathrm{Zn} n_{\text {extrac }}^{2+}\right]^{\text {concentration }}\right]
$$

11 Zinc ionic activity $(\gamma)$ of the polluted soil may be resumed as below:

$$
\log \left[Z^{2+}\right]_{I=0}^{\text {extrac. }}=\log \left(\frac{\Xi_{0}\{Z n\}^{\text {tot }}}{1-\Sigma \Xi\{Z n\}^{\text {tot }}}\right)-p H_{\mathrm{H}_{2} \mathrm{O}}-\log \mathrm{K}
$$

Statistica 10.0@ Package (StatSoft Polska Sp. z.o.o., Cracow, Poland) was used for statistical summary as well as the stepwise analysis. Graphs and linear relationships were elaborated by using the Excel@ 2010 (Microsoft Office 365, Warsaw, Poland) sheet facilities, as well as the Statistica $10.0 \odot$ Package.

\section{Results}

\subsection{Properties of Zn-Polluted Soil, Zeolite, Bentonite and ZB Blends}

Data resumed in Table 1 show that the Zn-polluted soil should be classified as sandy loam on the basis of the particle distribution (The soil type Anthrosols, Ap horizon was evaluated according to Soil Survey Staff, [25]). It is characterized by a slightly acidic $\mathrm{pH}$ and relatively low cation exchange capacity (CEC). The latter one was partly shaped also by the specific (total) surface area $\left(S S A_{E G M E}\right)$ with a value of $18.10 \mathrm{~m}^{2} \cdot \mathrm{g}^{-1}$, low enough to

\begin{tabular}{|c|c|}
\hline Parameter & Value \\
\hline Sand $(2-0.10 \mathrm{~mm}), \%$ & 65 \\
\hline Silt $(0.10-0.02 \mathrm{~mm}), \%$ & 20 \\
\hline Clay $(<0.02 \mathrm{~mm}), \%$ & 15 \\
\hline Organic carbon $\left(\mathrm{C}_{\mathrm{org}}\right) \%$ & 1.05 \\
\hline$p H_{\mathrm{H} 2 \mathrm{O}} / 1$ mole $\mathrm{KCl} \mathrm{dm}{ }^{-3}$ & $6.47 / 5.50$ \\
\hline$C E C^{\mathrm{a}}, \mathrm{cmol}_{(+)} \cdot \mathrm{kg}^{-1}$ & 15.1 \\
\hline$E C^{\mathrm{b}}\left(\mu \mathrm{S} \cdot \mathrm{cm}^{-1}\right)$ & 253.3 \\
\hline$S S A_{E G M E}{ }^{\mathrm{c}}\left(\mathrm{m}^{2} \cdot \mathrm{g}^{-1}\right)$ & 18.10 \\
\hline $\mathrm{CaO}(\%)$ & 4.40 \\
\hline $\mathrm{MgO}(\%)$ & 2.14 \\
\hline $\mathrm{P}_{2} \mathrm{O}_{5}(\%)$ & 0.29 \\
\hline $\mathrm{K}_{2} \mathrm{O}(\%)$ & 1.64 \\
\hline \multicolumn{2}{|c|}{ Zinc and Its Fractions } \\
\hline Total $\mathrm{Zn}$ content $\left(\mathrm{Zn} n_{t o t}, \mathrm{mg} \cdot \mathrm{kg}^{-1}\right)$ & 3988.0 \\
\hline Reactive $\mathrm{Zn}\left(\mathrm{Zn}_{\text {reac }}, \mathrm{mg} \cdot \mathrm{kg}^{-1}\right)$ & 93.0 \\
\hline Water soluble $\mathrm{Zn}\left(\mathrm{Zn}\right.$ act, $\left.\mathrm{mg} \cdot \mathrm{kg}^{-1}\right)$ & 1.55 \\
\hline
\end{tabular}
develop natural attenuation properties of the soil.

Table 1. Physical and chemical characteristics of the Zn-polluted soil.

${ }^{a}$ Cation exchange capacity, ${ }^{b}$ electrical conductivity, ${ }^{\mathrm{c}}$ specific surface area.

The level of pollution by $\mathrm{Zn}$ was very high, with the total content amounting to $3988.0 \mathrm{mg} \cdot \mathrm{kg}^{-1}$. For such low buffering capacities, this $\mathrm{Zn}$ content $\left(Z n_{t o t}\right)$ is a potential threat to the neighboring sites, due to a possibly enhanced mobility. On the other side, the reactive $\mathrm{Zn}$ fraction $\left(Z n_{\text {reac }}\right)$, as well as the water-soluble one $\left(Z n_{\text {act }}\right)$, represent $2.33 \%$ and $0.038 \%$ of $Z n_{\text {tot }}$, respectively. The $p H_{\mathrm{KCl}}=5.50$ is indicative of soil conditions that may favor decidedly $\mathrm{Zn}$ activity in the soil solution. 
The physical and chemical properties of the sorbents are reported in Table 2. Bentonite $(B)$ and the blends, where it prevailed, were characterized by the highest values of the whole parameters as compared to zeolite $(Z)$. A substantial difference was observed for the $p H$; zeolite was less alkaline $(p H=7.6)$ reversely to bentonite with a $\mathrm{pH}$ over $10(p H=10.3)$. The values of the electrical conductivity $(E C)$ revealed that this parameter was eight times higher for bentonite with reference to zeolite and in the case of the specific (total) surface area $\left(S S A_{E G M E}\right)$, as well as the cation exchange capacity $(C E C)$, a similar pattern was observed, but was less pronounced, i.e., 4 and 2 times, respectively.

Table 2. Physical and chemical characteristics of zeolite, bentonite and the ZeoBen $(Z B)$ blends.

\begin{tabular}{|c|c|c|c|c|c|c|c|}
\hline \multirow{2}{*}{$\begin{array}{l}\text { Mineral } \\
\text { Sorbents }\end{array}$} & \multirow{2}{*}{$p H_{\mathrm{H}_{2} \mathrm{O}}$} & \multirow{2}{*}{$\begin{array}{c}E C \\
\left(\mu \mathrm{S} \cdot \mathrm{cm}^{-1}\right)\end{array}$} & $S S A_{E G M E}$ & $S S A_{B E T}$ & $S S A_{I N T}$ & \multirow{2}{*}{$\begin{array}{c}C E C \\
\mathrm{cmol}_{(+)} \cdot \mathrm{kg}^{-1}\end{array}$} & \multirow{2}{*}{$\begin{array}{c}\mathrm{Zn} \\
\left(\mathrm{mg} \cdot \mathrm{kg}^{-1}\right)\end{array}$} \\
\hline & & & & $\mathrm{m}^{2} \cdot \mathrm{g}^{-1}$ & & & \\
\hline Zeolite $(Z)$ & 7.6 & 152 & 88.8 & 20.2 & 68.6 & 99.6 & 6.7 \\
\hline Bentonite $(B)$ & 10.3 & 1273 & 378.5 & 89.4 & 289.1 & 188.8 & 8.7 \\
\hline \multicolumn{8}{|c|}{ ZB Blends } \\
\hline ZB15/85 & 9.9 & 818 & 321.7 & 75.8 & 245.9 & 170.5 & 8.1 \\
\hline ZB30/70 & 9.3 & 781 & 287.2 & 67.6 & 219.7 & 167.9 & 8.0 \\
\hline ZB50/50 & 9.0 & 762 & 237.2 & 55.6 & 181.6 & 137.8 & 7.6 \\
\hline$Z B 70 / 30$ & 8.1 & 415 & 175.5 & 40.9 & 134.7 & 108.2 & 7.3 \\
\hline ZB85/15 & 7.8 & 373 & 119.1 & 27.4 & 91.67 & 105.6 & 7.0 \\
\hline
\end{tabular}

Data obtained for the blends ZB50/50, with an equal share of zeolite $(Z)$ and bentonite $(B)$, showed that the predominance of bentonite was visible for all parameters, since the values shifted more towards $B$ than $Z$. Three parameters, i.e., $p H_{\mathrm{H} 2 \mathrm{O}}, S S A_{B E T}, C E C$ identified at the zeolite and the blend $Z B 85 / 15$ require additional attention. In fact, the values were, in most cases, quite similar, particularly for the $p H$. The inactivation efficiency of these two sorbents, although different physically and structurally, should be helpful in analyzing the economic feasibility of some environmental prospects.

Processes activated in the course of pollution control in soils are basically mediated, and shaped by buffering mechanisms of which cation exchange capacity (CEC) plays the decisive role. The values did not fluctuate largely $\left(22.9<C E C<27.8 \mathrm{cmol}_{(+)} \cdot \mathrm{kg}^{-1}\right)$, (Table 3) among the blends, even after the aging process, which lasted 115 days, but some trends were observed with increasing $Z B$ rates. Two of them, i.e., $Z B 70 / 30$ and $Z B 85 / 15$, recorded the highest $C E C$ parameters, similar to treatments, where only bentonite $(B)$ was applied.

Table 3. Changes of buffering properties (CEC) of the treatment soils after application of mineral sorbents and 115 days of the aging process.

\begin{tabular}{|c|c|c|c|c|c|c|c|c|}
\hline \multirow{3}{*}{ Rate (\%) } & \multirow{3}{*}{$\begin{array}{c}\text { Rate }\left(\mathrm{g} \cdot \mathrm{kg}^{-1}\right. \\
\text { soil) }\end{array}$} & \multicolumn{7}{|c|}{ Mineral Sorbents } \\
\hline & & Zeolite & Bentonite & ZB15/85 & ZB30/70 & ZB50/50 & $Z B 70 / 30$ & ZB85/15 \\
\hline & & \multicolumn{7}{|c|}{$C E C\left(\mathrm{cmol}_{(+)} \cdot \mathrm{kg}^{-1}\right)$} \\
\hline \multicolumn{2}{|r|}{0} & \multicolumn{7}{|c|}{$15.1 \pm 1.27$ * } \\
\hline 0.25 & 2.5 & $23.7 \pm 0.47$ * & $25.2 \pm 0.39$ & $22.9 \pm 0.53$ & $23.0 \pm 0.48$ & $23.9 \pm 0.29$ & $24.5 \pm 0.32$ & $24.9 \pm 0.61$ \\
\hline 0.5 & 5.0 & $24.3 \pm 0.61$ & $26.1 \pm 0.61$ & $23.5 \pm 0.27$ & $23.8 \pm 0.67$ & $24.2 \pm 0.55$ & $25.5 \pm 0.87$ & $25.4 \pm 0.39$ \\
\hline 1.0 & 10.0 & $24.7 \pm 1.07$ & $27.7 \pm 0.77$ & $23.6 \pm 0.64$ & $24.1 \pm 0.73$ & $24.7 \pm 0.85$ & $26.0 \pm 0.98$ & $26.0 \pm 0.89$ \\
\hline 2.0 & 20.0 & $25.1 \pm 2.17$ & $27.8 \pm 1.67$ & $24.6 \pm 1.17$ & $24.4 \pm 0.97$ & $25.2 \pm 1.33$ & $26.0 \pm 1.05$ & $27.7 \pm 1.87$ \\
\hline
\end{tabular}

4.2. Active and Reactive Zn Fractions-Sorbents Efficiency-Quantification of Zeolite, Bentonite and $\mathrm{ZB}$ Blends

The content of active $\mathrm{Zn}$ fraction, i.e., water-soluble $\left(\mathrm{Z} n_{\text {act }}\right)$ and reactive, that is soluble in $0.11 \mathrm{M} \mathrm{CH}_{3} \mathrm{COOH}\left(\mathrm{Zn}_{\text {reac }}\right)$ in the particular treatments ( $\mathrm{Zn}$-polluted soil with sorbents) revealed a significant relationship for both experimental factors: type of sorbent and rates (Table 4). The greatest content of both fractions was observed in the treatments receiving 
either zeolite $(Z)$ or bentonite $(B)$. It should be stated that the $Z \mathrm{n}_{\text {act }}$ fraction was on average $100 \%$ lower as compared to $Z n_{\text {reac }}$. Next, a strong and significant relationship was established for the pairs $Z n_{\text {reac }}$ versus $Z n_{a c t}$, resulting in $R^{2}=0.87^{* *}(n=87, F \leq 0.01)$. The addition of sorbents led to a drastic decrease, about $55 \%$ of the $Z n_{\text {act }}$ fraction, with reference to the initial, i.e., $1.55 \mathrm{mg} \cdot \mathrm{kg}^{-1}$ (Figure 2). Further rates have induced its consecutive reduction, but the degree was less. In the case of the $Z B$ treatments, the $Z n_{\text {act }}$ pool was the lowest for the ZB85/15, particularly at the sorbent rate $20 \mathrm{~g} \cdot \mathrm{kg}^{-1}$ of soil (Table 4, Figures 2 and 3).

Table 4. Content of the active and reactive $\mathrm{Zn}$ fractions as affected by sorbents application.

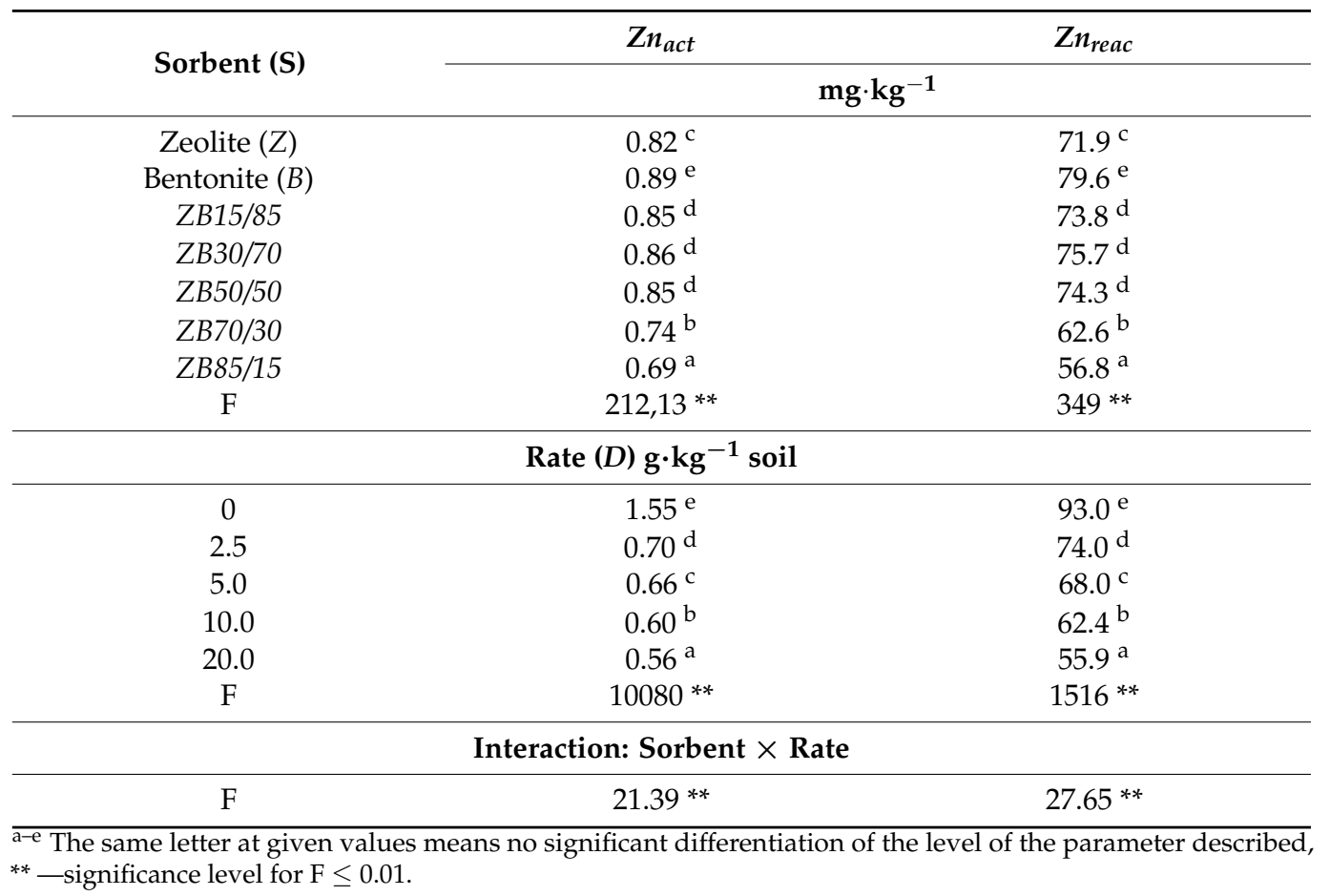

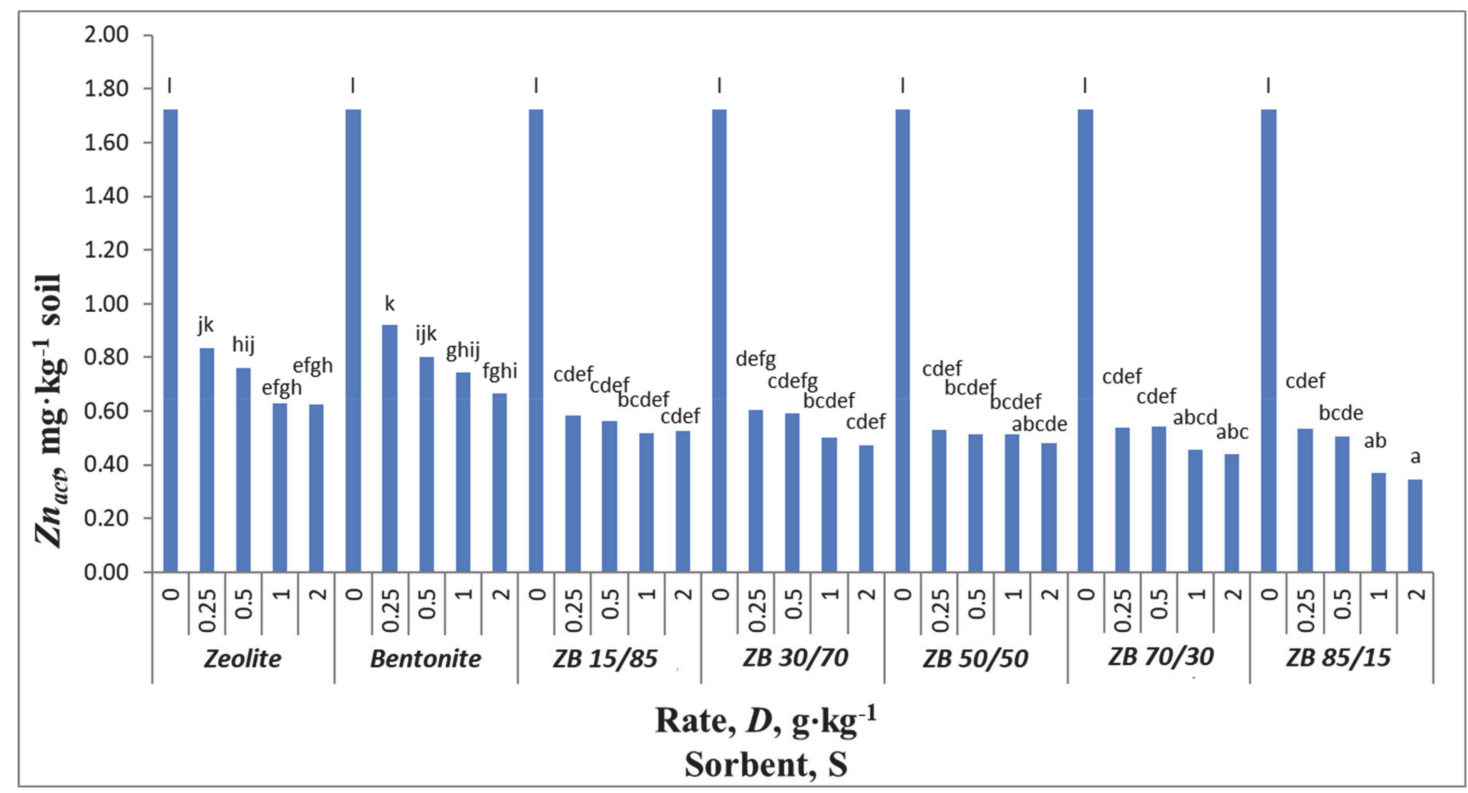

Figure 2. Content of the active zinc fraction $\left(Z n_{a c t}\right)$ on the background of interactions sorbent $(S)$ and rates $(D)$. Small letters a to 1 refer to statistical differences among the tested treatments, the same letter means no significant differentiation. 


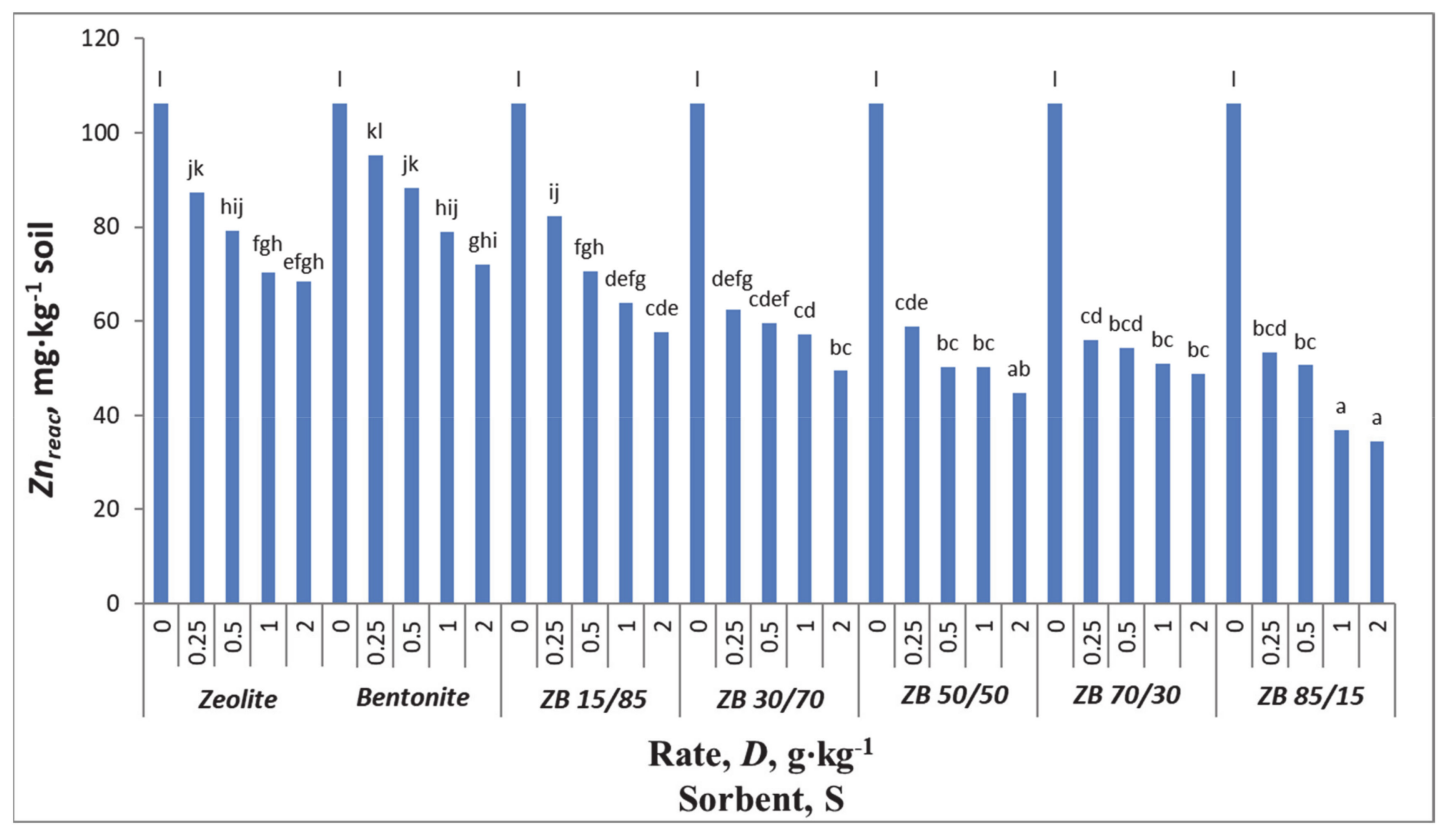

Figure 3. Content of the reactive zinc fraction $\left(Z n_{\text {reac }}\right)$ on the background of interactions sorbent $(S)$ and rates $(D)$. Small letters a to 1 refer to statistical differences among the tested treatments, the same letter means no significant differentiation.

The lowest differences were observed for the treatments with bentonite $(B)$ and those where it prevailed $(Z B 15 / 85, Z B 30 / 70)$ or shared equally ZB50/50. For all treatments, a quadratic model was obtained (Table 5). On this basis, the lowest minimal level of $Z n_{\text {act }}$ of $0.16 \mathrm{mg} \cdot \mathrm{kg}^{-1}$ of soil was recorded for $Z B 85 / 15$ at its optimal rate $\left(D_{\text {opt }}\right)$, amounting to $13.0 \mathrm{~g} \cdot \mathrm{kg}^{-1}$. On the other side, the highest $Z n_{\text {act }}$ content, i.e., $0.46 \mathrm{mg} \cdot \mathrm{kg}^{-1}$ of soil, was obtained at $D_{\text {opt }}=13.6 \mathrm{~g} \cdot \mathrm{kg}^{-1}$ in the treatment with bentonite. The differences in the $D_{\text {opt }}$ were small, with the $\mathrm{R}^{2}$ values in the range $0.70-0.81$ being indicative of the relatively weak fitting of the quadratic function to empirical data.

Table 5. Regression models elaborated for active $\mathrm{Zn}\left(\mathrm{Zn} n_{a c t}\right)$ fractions in treatments with sorbents after 115 days of aging.

\begin{tabular}{|c|c|c|c|c|}
\hline \multirow{2}{*}{ Sorbent } & $D_{o p t}{ }^{a}$ & $Z n_{a c t}(\min )^{b}$ & \multirow{2}{*}{ Equation } & \multirow{2}{*}{$\mathbf{R}^{2}$} \\
\hline & $\mathrm{g} \cdot \mathrm{kg}^{-1}$ & $\mathrm{mg} \cdot \mathrm{kg}^{-1}$ & & \\
\hline \multirow{2}{*}{ Zeolite (Z) } & $13.4^{\mathrm{c}}$ & 0.38 & $y=0.0063 D^{2}-0.169+1.510$ & 0.80 \\
\hline & $14.8^{\mathrm{d}}$ & 0.61 & $y=0.0004 D^{2}-0.012 D+0.697$ & 0.98 \\
\hline \multirow{2}{*}{ Bentonite $(B)$} & 13.8 & 0.47 & $y=0.0055 D^{2}-0.152 D+1.521$ & 0.80 \\
\hline & 17.2 & 0.62 & $y=0.001 D^{2}-0.034 D+0.915$ & 0.99 \\
\hline \multirow{2}{*}{ ZB15/85 } & 12.9 & 0.21 & $y=0.0073 D^{2}-0.188 D+1.419$ & 0.70 \\
\hline & - & - & $y=-0.0149 D+0.821$ & 0.92 \\
\hline \multirow{2}{*}{ ZB30/70 } & 13.2 & 0.19 & $y=0.0071 D^{2}-0.188 D+1.431$ & 0.72 \\
\hline & 19.2 & 0.60 & $y=0.0006 D^{2}-0.023 D+0.823$ & 0.72 \\
\hline \multirow{2}{*}{ ZB50/50 } & 13.0 & 0.17 & $y=0.0073 D^{2}-0.189 D+1.395$ & 0.67 \\
\hline & - & - & $y=-0.0056 D+0.724$ & 0.96 \\
\hline \multirow{2}{*}{$Z B 70 / 30$} & 13.2 & 0.13 & $y=0.0074 D^{2}-0.195 D+1.411$ & 0.71 \\
\hline & 17.0 & 0.48 & $y=0.0006 D^{2}-0.0204 D+0.652$ & 0.95 \\
\hline \multirow{2}{*}{ ZB85/15 } & 13.3 & 0.05 & $y=0.0078 D^{2}-0.207 D+1.421$ & 0.75 \\
\hline & 14.8 & 0.43 & $y=0.0006 D^{2}-0.018 D+0.566$ & 0.95 \\
\hline
\end{tabular}

a Optimal rate, ${ }^{b}$ minimal $Z n_{\text {act }}$ level, c,d: calculated with and without considering the control treatment, respectively.

The omission of the control treatment has outlined a much more complex relationship (Table 5). For zeolite $(Z)$ and bentonite $(B)$ treatments, a quadratic model similar to those identified for $Z B 30 / 70, Z B 70 / 30$ and $Z B 85 / 15$ was established. These models revealed the 
highest $D_{\text {opt }}$ value in the range $14.8-19.2 \mathrm{~g} \cdot \mathrm{kg}^{-1}$ of soil, but for $Z B 15 / 85$ and $Z B 50 / 50$, each consecutive sorbent rate led to a linear decrease of $Z n_{\text {act }}$.

Trends in the content of the $Z n_{\text {reac }}$ fractions reflected those observed for the $Z n_{\text {act }}$, but the differences in the case of $Z n_{\text {reac }}$ between the control and the first-rate of sorbents were much more lower (Figure 3). This fraction decreased along with increasing the rates, and the greatest reduction occurred in the treatment $\mathrm{ZB} 85 / 15$ at the rate $20 \mathrm{~g} \cdot \mathrm{kg}^{-1}$. All treatments were characterized by quadratic models with $R^{2}$ values indicative of a good fit to empirical $Z n_{\text {reac }}$ data (Table 6), except for the bentonite (B), which described a linear function. The minimal $Z n_{\text {reac }}$ pool, $33.18 \mathrm{mg} \mathrm{Zn} \mathrm{kg}^{-1}$ of soil was obtained at $Z B 85 / 15$, i.e., with the prevalence of zeolite, and at the lowest optimal rate $14.0 \mathrm{~g} \cdot \mathrm{kg}^{-1}$ of soil. On the other side, the highest minimal $Z n_{\text {reac }}$ level amounting to $61.8 \mathrm{mg} \mathrm{Zn} \mathrm{kg}{ }^{-1}$ of soil was recorded in the case of the treatment $Z B 30 / 70$ at its optimal rate $16.0 \mathrm{~g} \cdot \mathrm{kg}^{-1}$. Similarly, the highest minimal level of $54.78 \mathrm{mg} \cdot \mathrm{kg}^{-1}$ has been identified at the rate $19.3 \mathrm{~g} \mathrm{~kg}^{-1}$ of the sorbent ZB85/15.

Table 6. Regression models elaborated for reactive $\mathrm{Zn}(\mathrm{Zn}$ reac $)$ fractions in treatments with sorbents after 115 days of aging.

\begin{tabular}{cccccc}
\hline \multirow{2}{*}{ Sorbent } & $\boldsymbol{D}_{\text {opt }} \mathbf{a}^{\mathbf{a}}$ & $\mathbf{Z n}_{\text {reac }}(\mathbf{m i n})^{\mathbf{b}}$ & Equation & \multirow{2}{*}{$\mathbf{R}^{\mathbf{2}}$} \\
\cline { 2 - 3 } & $\mathbf{g} \cdot \mathbf{k g}^{-\mathbf{1}}$ & $\mathbf{m g} \cdot \mathbf{k g}^{-\mathbf{1}}$ & & & \\
\hline Zeolite $(Z)$ & 14.2 & 57.51 & $y=0.153 D^{2}-4.330 D+88.183$ & 0.86 \\
Bentonite $(B)$ & - & - & $y=-1.422 D+90.235$ & 0.94 \\
ZB15/85 & 19.3 & 54.78 & $y=0.100 D^{2}-3.873 D+92.238$ & 0.99 \\
ZB30/70 & 16.0 & 61.80 & $y=0.113 D^{2}-3.628 D+90.833$ & 0.96 \\
ZB50/50 & 17.1 & 60.02 & $y=0.100 D^{2}-3.440 D+89.474$ & 0.92 \\
ZB70/30 & 14.5 & 41.53 & $y=0.213 D^{2}-6.174 D+86.257$ & 0.87 \\
ZB85/15 & 14.0 & 33.18 & $y=0.256 D^{2}-7.164 D+83.243$ & 0.80 \\
\hline
\end{tabular}

a Optimal rate, ${ }^{\mathrm{b}}$ minimal $Z n_{\text {reac }}$ level.

\subsection{The ZB50/50 + Phosphorus Versus Active and Reactive Zn Fractions}

The contents of $Z n_{\text {act }}$ as well as $Z n_{\text {react }}$ after the addition of the $Z B 50 / 50$ sorbent, exhibited a significant relationship referring to the rate of sorbent and phosphorus (Table 7). The highest level of both forms of zinc was observed at the treatment with the lowest sorbent rate. Practically, any increase in the sorbent rate led to a gradual decrease of the reported $\mathrm{Zn}$ forms. It should be stressed that the significantly lowest content of $\mathrm{Zn}$ (all forms included) was obtained with the highest rate of phosphorus (P).

The incorporation of the sorbent induced slight alterations of the $Z n_{\text {reac }}$ fractions (Figure 4), but the latter decreased gradually with increasing the rates. Next, the addition of phosphorus $(\mathrm{P})$ reduced the level of $Z n_{\text {reac }}$ and this was visible even among the sorbent rates. The lowest content of $Z n_{\text {reac }}$ occurred practically at the highest both sorbent (i.e., $\left.20 \mathrm{~g} \mathrm{~kg}^{-1}\right)$ as well as phosphorus $\left(0.40 \mathrm{~g} \cdot \mathrm{kg}^{-1}\right)$ rate. The regression model reported in Table 8 was of a quadratic function (at sorbent rate $=20 \mathrm{~g} \cdot \mathrm{kg}^{-1}$ ), with phosphorus rate as the independent variable $(D P)$. The lowest $Z n_{\text {reac }}$ fraction of $0.23 \mathrm{mg} \cdot \mathrm{kg}^{-1}$ soil was obtained at the sorbent rate of $20 \mathrm{~g} \cdot \mathrm{kg}^{-1}$ with an optimal $\mathrm{P}\left(D_{\text {opt }}\right)$ level amounting to $0.356 \mathrm{~g} \mathrm{P} \cdot \mathrm{kg}^{-1}$ soil. For two sorbent rates, i.e., 5 and $10 \mathrm{~g} \cdot \mathrm{kg}^{-1}$ soil, no statistically significant regressions were obtained.

Table 7. Content of the active and reactive $\mathrm{Zn}$ fractions as affected by the application of the sorbent ZB50/50, enriched with phosphorus as triple superphosphate (TSP).

\begin{tabular}{ccc}
\hline Rate $(\mathbf{D})$ of $\mathbf{Z B 5 0 / 5 0}$ & $\mathrm{Zn}_{\text {act }}$ & $\mathbf{Z}$ \\
$\mathbf{g} \cdot \mathbf{k g}^{\mathbf{- 1}}$ soil & & $\mathbf{m g} \cdot \mathbf{k g}_{\text {reac }}$ \\
\hline 2.5 & $0.48^{\mathrm{c}}$ & \\
5.0 & $0.44^{\mathrm{b}}$ & $53.8^{\mathrm{d}}$ \\
10.0 & $0.42^{\mathrm{b}}$ & $49.7^{\mathrm{c}}$ \\
\hline
\end{tabular}


Table 7. Cont.

\begin{tabular}{|c|c|c|}
\hline \multirow{2}{*}{$\begin{array}{c}\text { Rate }(D) \text { of } Z B 50 / 50 \\
\mathrm{~g} \cdot \mathrm{kg}^{-1} \text { soil }\end{array}$} & $Z n_{\text {act }}$ & $Z n_{\text {reac }}$ \\
\hline & \multicolumn{2}{|c|}{$\mathrm{mg} \cdot \mathrm{kg}^{-1}$} \\
\hline 20.0 & $0.35^{\mathrm{a}}$ & $38.4^{\mathrm{a}}$ \\
\hline $\mathrm{F}$ & $39.29 * * *$ & $198.80^{* * *}$ \\
\hline \multicolumn{3}{|c|}{ Rate of Phosphorus $(D P), \% \mathrm{P} \cdot \mathrm{g}^{-1}$ sorbent } \\
\hline 0 & $0.50^{\mathrm{d}}$ & $51.0^{\mathrm{d}}$ \\
\hline 0.25 & $0.45^{\mathrm{c}}$ & $55.2^{\mathrm{c}}$ \\
\hline 0.50 & $0.45^{\mathrm{c}}$ & $49.2^{\mathrm{c}}$ \\
\hline 1.00 & $0.38^{\mathrm{b}}$ & $41.8^{\mathrm{b}}$ \\
\hline 2.00 & $0.32^{\mathrm{a}}$ & $37.2^{\mathrm{a}}$ \\
\hline $\mathrm{F}$ & $60.92 * * *$ & $195.26^{* * *}$ \\
\hline \multicolumn{3}{|c|}{ Interaction: $D \times D P$} \\
\hline $\mathrm{F}$ & $10.40 * * *$ & $13.27^{* * *}$ \\
\hline
\end{tabular}

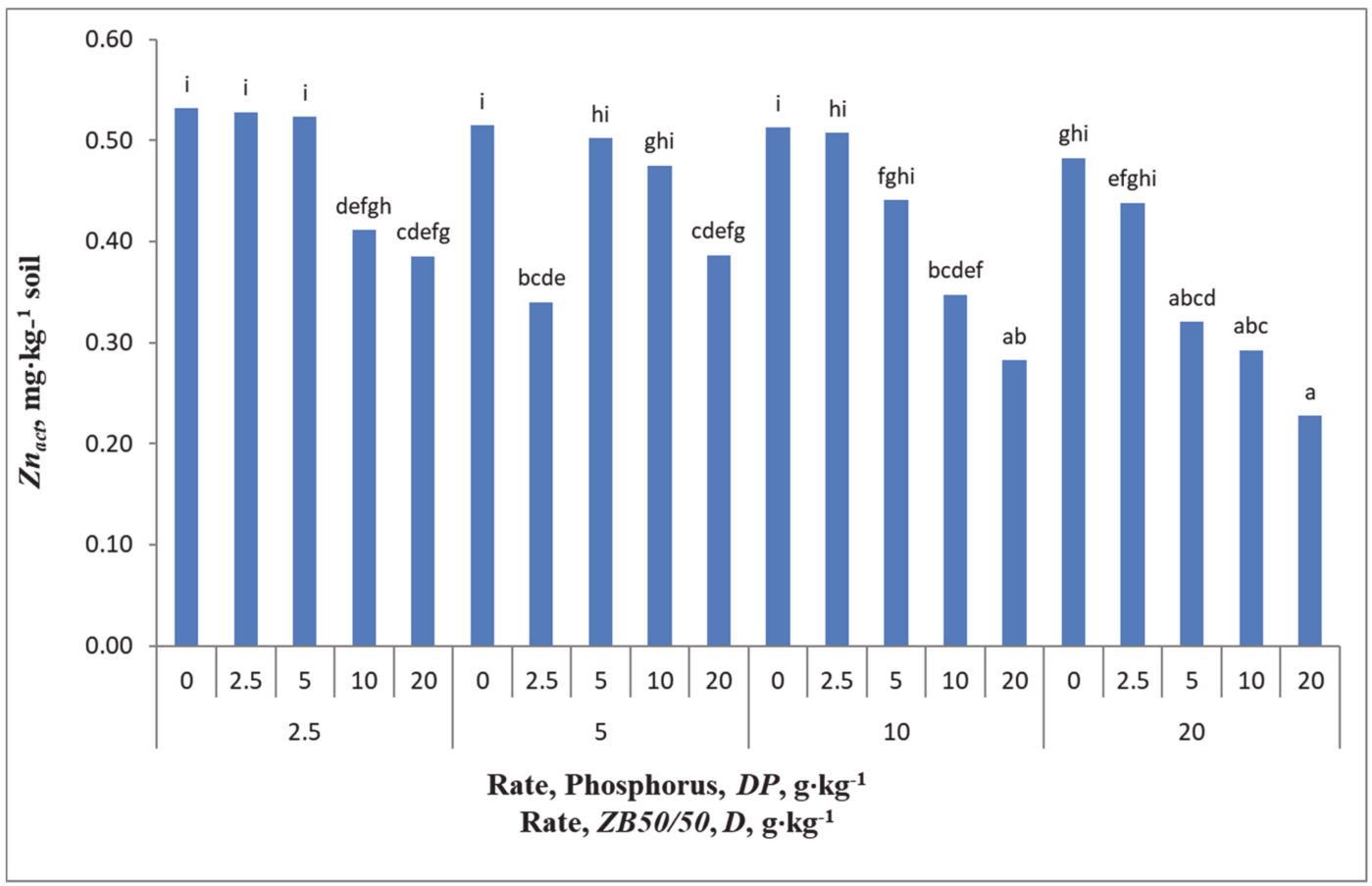

Figure 4. Content of the active zinc fraction $\left(Z n_{a c t}\right)$ on the background of interactions $Z B 50 / 50(D)$ and phosphorus $(D P)$ rates. Small letters a to 1 refer to statistical differences among the tested treatments, the same letter means no significant differentiation.

Table 8. Regression models elaborated for active $\mathrm{Zn}\left(\mathrm{Zn} n_{a c t}\right)$ fractions in treatments with sorbents ZB50/50 enriched with phosphorus as triple superphosphate (TSP) after 115 days of aging.

\begin{tabular}{|c|c|c|c|c|}
\hline \multirow{2}{*}{$\begin{array}{c}\text { Rate }(D) \text { of } Z B 50 / 50 \\
\mathrm{~g} \cdot \mathrm{kg}^{-1} \text { soil }\end{array}$} & $D_{o p t}{ }^{a}$ & $Z n_{a c t}(\min )^{b}$ & \multirow{2}{*}{ Equation } & \multirow{2}{*}{$\mathbf{R}^{2}$} \\
\hline & $\mathrm{g} \cdot \mathrm{kg}^{-1}$ & $\mathrm{mg} \cdot \mathrm{kg}^{-1}$ & & \\
\hline 2.5 & - & - & $y=-3.345 D P^{c}+0.539$ & 0.86 \\
\hline 5.0 & - & - & - & - \\
\hline 10.0 & - & - & - & - \\
\hline 20.0 & 0.354 & 0.23 & $y=2.062 D P^{2}-1.458 D P+0.483$ & 0.95 \\
\hline
\end{tabular}

a Optimal rate, ${ }^{\mathrm{b}}$ minimal $\mathrm{Zn}$ act level, ${ }^{\mathrm{c}}$ rate of phosphorus. 
The reactive $\mathrm{Zn}\left(\mathrm{Zn} n_{\text {reac }}\right)$ fraction displayed a trend similar to that observed for the active $\left(Z n_{a c t}\right)$ one. A decrease of this fraction took place after the incorporation of $Z B 50 / 50$ enriched with phosphorus (P), (Figure 5). Each consecutive sorbent rate beyond $2.5 \mathrm{~g} \cdot \mathrm{kg}^{-1}$ induced a decrease of the $Z n_{\text {reac }}$ fraction, with its lowest levels being recorded at the rates 10 and $20 \mathrm{~g} \cdot \mathrm{kg}^{-1}$ and the highest $\mathrm{P}$ addition (i.e., $20 \mathrm{~g} \cdot \mathrm{kg}^{-1}$ ). The highest sorbent rate exhibited a response with phosphorus which was described by a quadratic regression model (Table 9$)$. This rate shaped the optimal rate $\left(D P_{\text {opt }}\right)$ at a high level, amounting to $0.369 \mathrm{~g} \cdot \mathrm{P} \cdot \mathrm{kg}^{-1}$ soil, whereas the lowest $Z n_{\text {reac }}$ fraction equaled to $28.2 \mathrm{mg} \cdot \mathrm{kg}^{-1}$ soil.

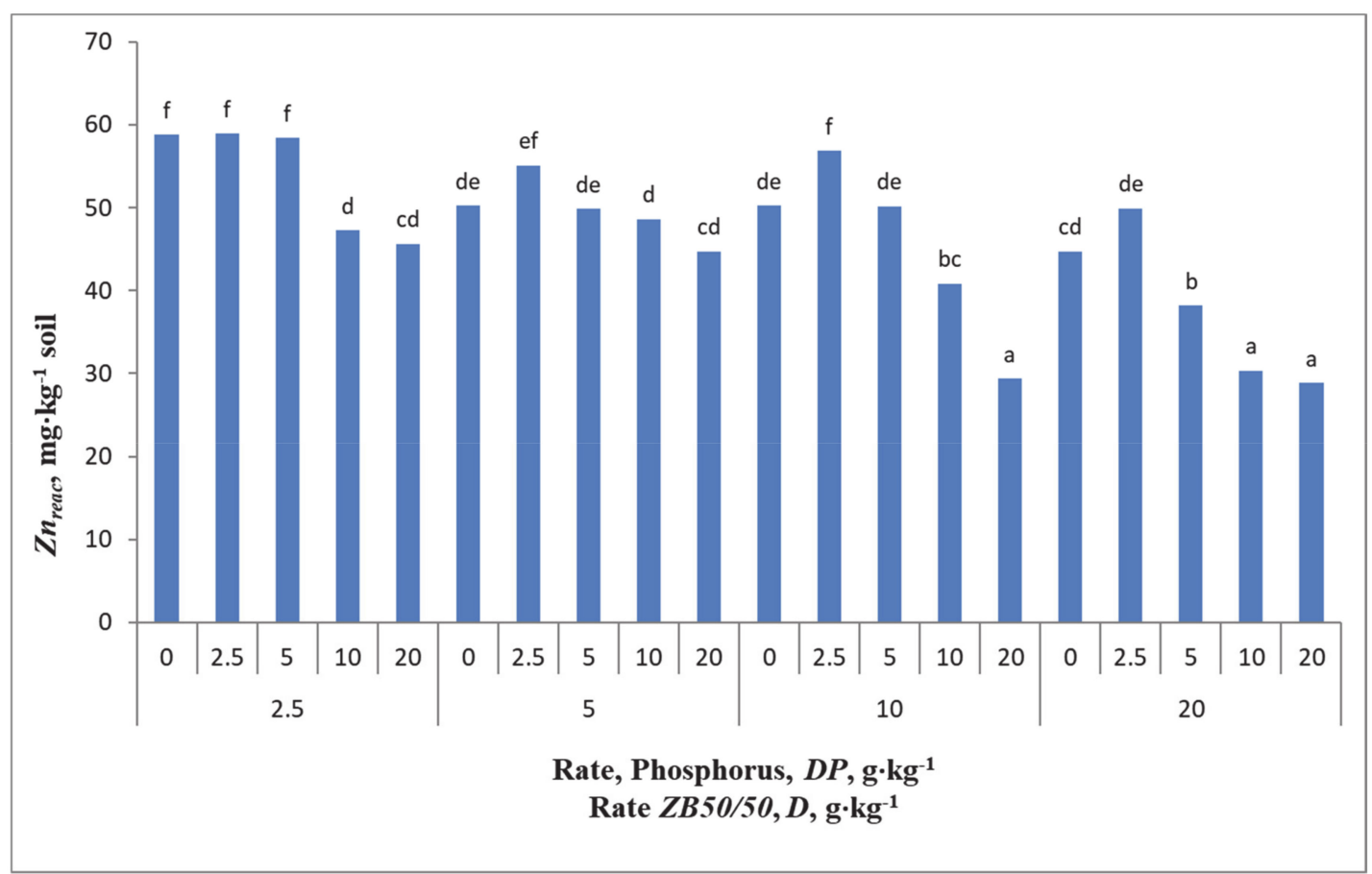

Figure 5. Content of the reactive zinc fraction $\left(Z n_{\text {reac }}\right)$ on the background of interactions $Z B 50 / 50(D)$ and phosphorus $(D P)$ rates. Small letters a to 1 refer to statistical differences among the tested treatments, the same letter means no significant differentiation.

Table 9. Regression models elaborated for reactive $\mathrm{Zn}\left(\mathrm{Zn} n_{\text {reac }}\right)$ fractions in treatments with sorbents ZB50/50 enriched with phosphorus as triple superphosphate (TSP) after 115 days of aging.

\begin{tabular}{|c|c|c|c|c|}
\hline \multirow{2}{*}{$\begin{array}{c}\text { Rate }(D) \text { of } Z B 50 / 50, \\
\mathrm{~g} \cdot \mathrm{kg}^{-1} \text { soil }\end{array}$} & $D_{o p t}{ }^{a}$ & $Z n_{a c t}(\min )^{b}$ & \multirow{2}{*}{ Equation } & \multirow{2}{*}{$\mathbf{R}^{2}$} \\
\hline & $\mathrm{g} \cdot \mathrm{kg}^{-1}$ & $\mathrm{mg} \cdot \mathrm{kg}^{-1}$ & & \\
\hline 2.5 & - & - & $y=-308.47 D P^{c}+59.599$ & 0.82 \\
\hline 5.0 & - & - & $y=-76.75 D P+52.603$ & 0.66 \\
\hline 10.0 & - & - & $y=-45.67 D P+47.287$ & 0.89 \\
\hline 20.0 & 0.369 & 28.23 & $y=150.08 D P^{2}-110.72 D P+48.65$ & 0.81 \\
\hline
\end{tabular}

a Optimal rate, ${ }^{\mathrm{b}}$ minimal $\mathrm{Zn}$ reac level, ${ }^{\mathrm{c}}$ rate of phosphorus.

\subsection{Evaluation of Potential $\mathrm{Zn}$ Activity}

Ionic activity is a complex process of interactions in soil that are shaped by the $\mathrm{pH}$, cation exchange capacity (CEC) and the content of zinc. Then, it may focus on the geochemical potential of Zn, particularly in terms of its mobility in the soil. The ranges as below (Table 10) are suggested by the authors for evaluating the behavior of the two tested zinc fractions, i.e., $Z n_{\text {act }}$ and $Z n_{\text {reac }}$ of the particular treatments: 
Table 10. Ranges and description used for evaluating zinc activities of the current study.

\begin{tabular}{cc}
\hline Ranges of $\mathbf{Z n}$ Activities $(\gamma \mathbf{Z n})\left(\mathbf{m m o l} \cdot \mathbf{d m}^{-3}\right)$ & Description \\
\hline $0<\gamma Z n<-5.0$ & High \\
$-5.1<\gamma Z n<-10.0$ & Moderate \\
$-10.1<\gamma Z n<-15.0$ & Low \\
\hline
\end{tabular}

From these ranges, it appears that the higher the value, the highest the Zn activity in the soil solution. However, for the conditions of the current study, the values vary from -11.5 to $-12.5 \mathrm{mmol} \cdot \mathrm{dm}^{-3}$ for the $Z n_{\text {reac }}$ and from -12.5 to $-13.5 \mathrm{mmol} \cdot \mathrm{dm}^{-3}$ in the case for the $Z n_{\text {act }}$ fractions, as illustrated by Figures 6 and 7 .

Soil reaction $(p H)$ appeared as the master parameter, which shaped the most the activities of both fractions, particularly the $Z n_{\text {reac }}$, with $\mathrm{R}^{2}=0.57$. It implies that about $60 \%$ of $\mathrm{Zn}$ reactions, as induced by the incorporation of the sorbent, was $\mathrm{pH}$-dependent. Sorbents, which shifted the most the $\mathrm{pH}$, were much $\mathrm{pH}$-effective and concerned those with the highest share of bentonite $(B): Z B 15 / 85, Z B 30 / 70$ and ZB50/50. A similar pattern was observed for the $Z n_{\text {act }}$ pool, but $p H$ was less determinant of its activity. The evaluation made on the basis of criteria listed in Table 10 implies that in both cases, $\mathrm{Zn}$ activity was reduced, even at a $\mathrm{pH}$ of about 6.80 with $\gamma \mathrm{Zn}$ about $11.5 \mathrm{mmol} \cdot \mathrm{dm}^{-3}$. This value was lower than the limit reported as $-10.1 \mathrm{mmol} \cdot \mathrm{dm}^{-3}$.

Buffering properties expressed in terms of the $C E C$ were also altered by the incorporation of the sorbents. Mechanisms involved in shaping this parameter are $\mathrm{pH}$ dependent, and an integral part of the CEC. The effect of the latter one on $\mathrm{Zn}$ activities was similar in terms of the values of $\gamma Z n$, with the difference that $C E C$ was not a strong determinant for regulating $Z n_{\text {act }}$ and $Z n_{\text {reac }}$ (Figure 7). This is reflected by the $\mathrm{R}^{2}$ values, quite similar, then for $\gamma Z n_{\text {act }}$, it was 0.32 as compared to $\gamma Z n_{\text {reac }}-0.28$.

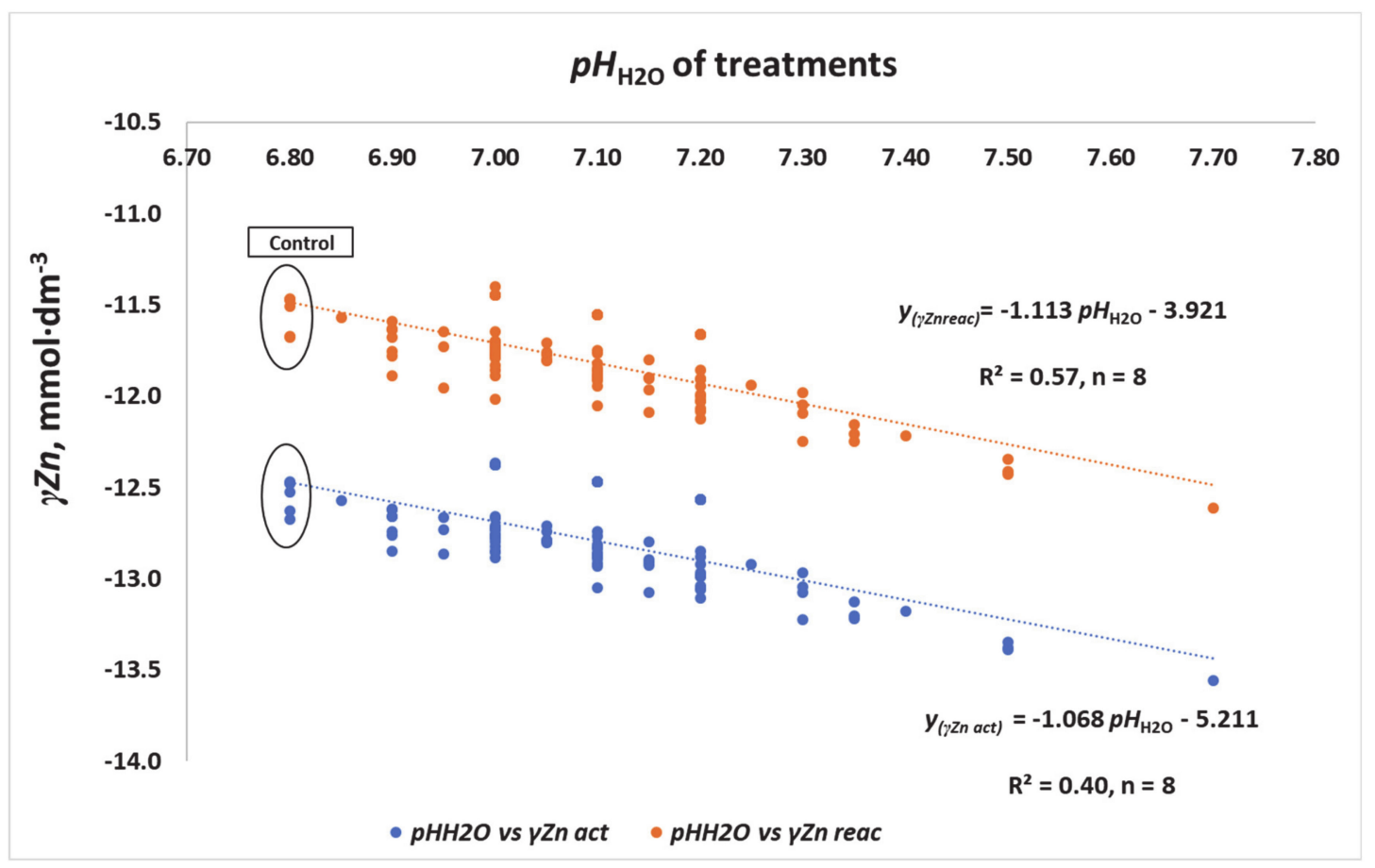

Figure 6. Relationships established for the pairs $\mathrm{Zn}$ activities of the active $\left(\mathrm{Z} n_{\text {act }}\right)$ and reactive $\left(\mathrm{Z} n_{\text {reac }}\right)$ fractions versus $p H$ of the sorbents treated soil. 


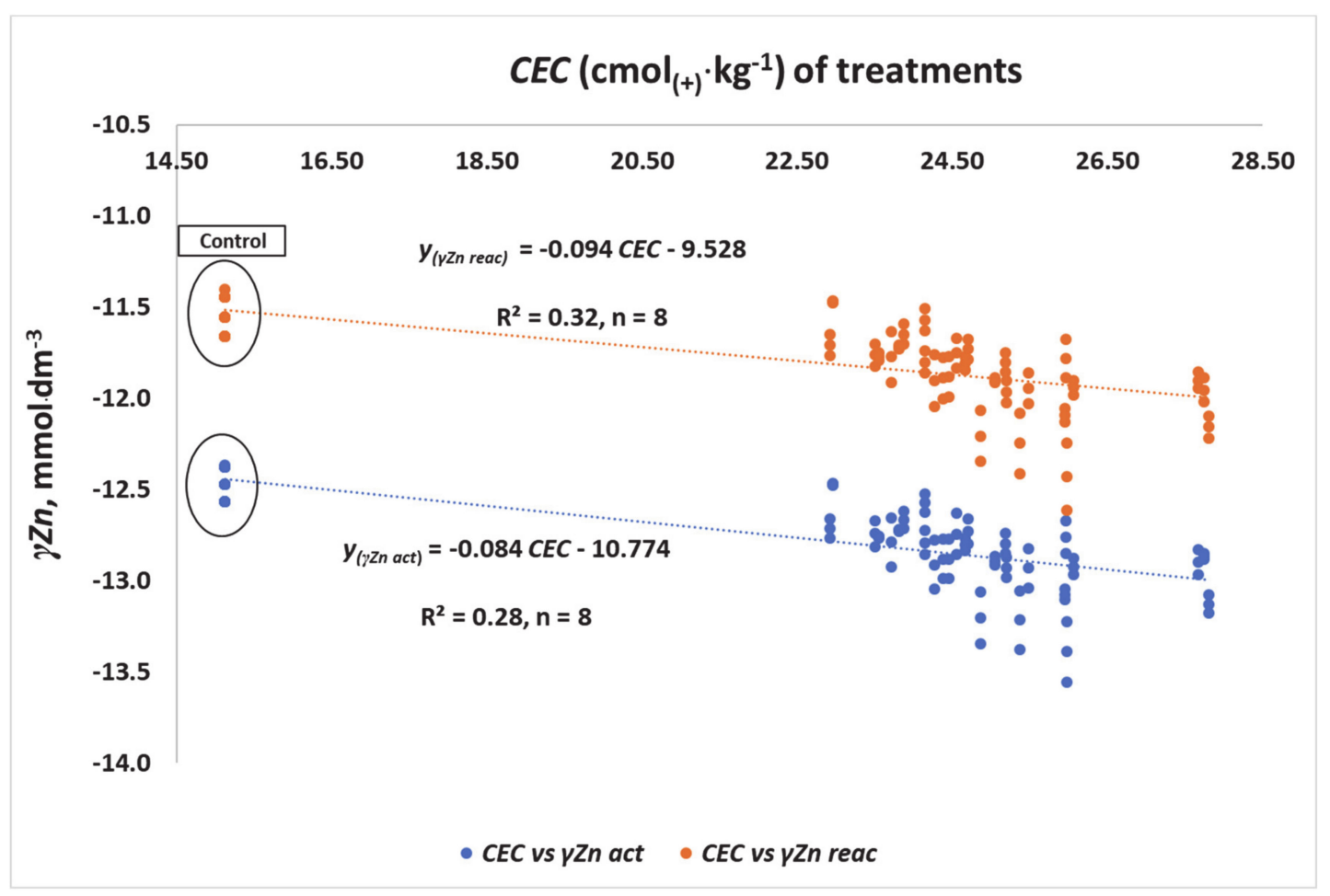

Figure 7. Relationships established for the pairs $\mathrm{Zn}$ activities of the active $\left(Z n_{\text {act }}\right)$ and reactive $\left(Z n_{\text {reac }}\right)$ fractions versus $C E C$ of the sorbents treated soil.

The ranges as listed below outline the dynamic character of the tested $\mathrm{Zn}$ fractions:

- $23.0<C E C<25.5 \mathrm{cmol}_{(+)} \cdot \mathrm{kg}^{-1}$

- $\quad-11.5<\gamma \mathrm{Zn}_{\text {reac }}<-12.0 \mathrm{mmol} \cdot \mathrm{dm}^{-3}$

- $\quad-12.5<\gamma Z n_{\text {act }}<-13.0 \mathrm{mmol} \cdot \mathrm{dm}^{-3}$

These patterns indicate that about 2 CEC units have been activated for controlling about 0.50 units of either $\gamma Z n_{\text {reac }}$ or $\gamma Z n_{\text {act }}$. Such ratio implies that zinc under current conditions of the remediation process was potentially mobile (active). The incorporation of zeolite and bentonite, particularly the ZB blends, significantly extended buffering capacities (CEC) to counteracting Zn lability.

\section{Discussion}

Metal toxicities to the flora as well as fauna depend less on their total content in the soil, but particularly on the concentrations of the mobile (active) forms, i.e., ions, chelates, in the soil solution. Therefore, the basic task in remediation endeavors should be the retrogradation of these metal fractions. The practice runs through the incorporation of various organic and/or inorganic materials; zeolite, bentonite or phosphorus compounds, among others [36-38].

The remediation effects of the tested sorbents, i.e., zeolite $(Z)$, bentonite $(B)$ and their blends (ZB): ZB15/85, ZB30/70, ZB50/50, ZB70/30, ZB85/15 (Table 2) were evaluated on the basis of geochemical changes of two $\mathrm{Zn}$ forms, (1) active $\left(\mathrm{Zn} n_{\text {act }}\right)$, i.e., water-soluble and (2) reactive $\left(Z n_{\text {reac }}\right)$, for the fractions extracted with 0.11 mole $\mathrm{CH}_{3} \mathrm{COOH} \mathrm{dm}{ }^{-3}$. According to Lee and Ahn [39], the test 0.11 mole $\mathrm{CH}_{3} \mathrm{COOH} \mathrm{dm}{ }^{-3}$ reflects very well the soil potential for fixing $\mathrm{Cd}, \mathrm{Zn}$ and $\mathrm{Cu}$. We considered, therefore, that changes observed with the $Z n_{\text {reac }}$ fractions may be describing the capacity of the sorbents-treated $\mathrm{Zn}$-polluted soil for inactivating $\mathrm{Zn}$.

Trends in the total contents of zinc $\left(Z n_{t o t}\right)$ should be first taken into consideration. Investigations have revealed that the type of sorbents plays a secondary role in the stabilization (inactivation) process, contrarily to the rates. The lowest sorbents rate, i.e., $2.5 \mathrm{~g} \cdot \mathrm{kg}^{-1}$ 
of soil, and considering the soil mass at $3000 \mathrm{t} \cdot \mathrm{ha}^{-1}$ (soil layer $0.2 \mathrm{~m}$ and density $1.5 \mathrm{t} \cdot \mathrm{m}^{-3}$ ) was equivalent to $7.5 \mathrm{t} \cdot \mathrm{ha}^{-1}$, whereas the highest one, $20 \mathrm{~g} \cdot \mathrm{kg}^{-1}$ soil represented $60 \mathrm{t} \cdot \mathrm{ha}^{-1}$ of sorbents applied to the $\mathrm{Zn}$-polluted soil. The total $\mathrm{Zn}$ content $(\mathrm{Zn}$ tot $)$ at the initial soil not treated with sorbents amounted to $3.98 \mathrm{~g} \cdot \mathrm{kg}^{-1}$ in total $11.96 \mathrm{t} \cdot \mathrm{ha}^{-1}$ of the metal in the soil. The application of $20 \mathrm{~g} \cdot \mathrm{kg}^{-1}$ soil decreased the level, on average, to $2.12 \mathrm{~g} \cdot \mathrm{kg}^{-1}$ soil, that is to $6.37 \mathrm{t} \cdot \mathrm{ha}^{-1}$. The mean degree of $Z n_{\text {tot }}$ inactivation for all treatments is described by the equation:

$$
Z n_{\text {tot }}=2.1 D^{2}-68.9 D+2673, \text { for } \mathrm{n}=84, \mathrm{R}^{2}=0.92 \text { and } \mathrm{P} \leq 0.001
$$

$D_{\text {opt }}=16.4 \mathrm{~g} \cdot \mathrm{kg}^{-1}$ and $\mathrm{Zn}_{\text {totmin }}=2108 \mathrm{mg} \cdot \mathrm{kg}^{-1}$,

where,

$\mathrm{Zn}_{\text {tot }}$ - total $\mathrm{Zn}$ content, $\mathrm{mg} \cdot \mathrm{kg}^{-1}$ soil,

$D$ —sorbent rate, $\mathrm{g} \cdot \mathrm{kg}^{-1}$ soil,

$D_{\text {opt }}$-optimal sorbent rate, $\mathrm{g} \cdot \mathrm{kg}^{-1}$ soil,

$\mathrm{Zn}_{\text {totmin }}$ - minimal $\mathrm{Zn}$ content after the incorporation of $D_{\text {opt }}$ of the sorbent, $\mathrm{mg} \cdot \mathrm{kg}^{-1}$ soil.

From this equation, it appears that the application of any investigated sorbent (i.e., zeolite, bentonite and the $Z B$ ) to the soil at the rate of about $50 \mathrm{t} \cdot \mathrm{ha}^{-1}$ will result in a permanent inactivation of a significant amount of $\mathrm{Zn}$, evaluated to about $1.84 \mathrm{t} \cdot \mathrm{ha}^{-1}$. This process suggested in the current study could be viewed as an efficient chemical remediation achievement. These data corroborate, a limited number of studies performed in China on the role of zeolite in immobilizing trace metals in soils [40,41].

Soil reaction, i.e., $\mathrm{pH}$, is considered as one of the factors significantly regulating the behavior of trace metals. According to Diatta and Kociałkowski [42], the mobility of zinc in the soil raises when $p H$ falls below 6.0-6.5. In the case of the current study, the mean values for $p H$ of the treatments with sorbents varied within the range of 6.85 to 7.70 (Figure 6). This parameter may be shaping the value of the first hydrolysis degree, which fluctuates between 6.2 and 7.0 for zinc [43]. Above this value, hydroxy ions are being formed, like $\mathrm{Zn}(\mathrm{OH})^{+}$and much more $\mathrm{Zn}(\mathrm{OH})_{2}$ under alkaline conditions (nearly $\mathrm{pH} 8$ ). Two important aspects of the stabilizing effect of zeolite on soil artificially polluted with cadmium were pointed out by Lin et al. [40]. The first was the increase in the values of the cation exchange capacity $(C E C)$, and the second dealt with $\mathrm{pH}$. In a study on the adsorption of zinc and copper at the savannah Bt soil layer, Agbenin and Olojo [44] reached a maximal $\mathrm{Zn}$ adsorption at $\mathrm{pH}>6.8$.

The $\mathrm{pH}$ of the zeolite used in our study was 7.6 as compared to bentonite, 10.3. The increase in the share of zeolite at the blends induced a decrease in $p H$ from $9.9(Z B 15 / 85)$ to a level of $7.8(Z B 85 / 15)$. The $p H$ of the treatments with sorbents was around 7.0 (varied 6.85 and 7.70), indicating moderate variation, but slightly higher values (7.2-7.4) were observed with bentonite. The greatest decrease in the contents of active, as well as reactive $\mathrm{Zn}$ fractions for the treatments with zeolite and the blends, where it prevails, are indicative of larger $C E C$ values. The $\mathrm{pH}$ should be decidedly taken into consideration since the slightly alkaline $\mathrm{pH}$ of the zeolite induces ionic complexation of metals at the surface of minerals [45].

The levels of active $\mathrm{Zn}$ fractions $\left(\mathrm{Zn}_{\text {act }}\right)$ after 115 days of treatment aging decreased significantly just after the application of the first sorbent rate $\left(2.5 \mathrm{~g} \cdot \mathrm{kg}^{-1}\right.$ soil). In the case of zeolite $(Z)$, the reduction was $53-54 \%$, but for bentonite $(B)$, slightly lower $(47 \%)$. In the group of the blends $(Z B)$, the much more significant decrease, within the range $66-71 \%$ was recorded in the treatments with ZB85/15, with prevailing zeolite $(Z)$. Each consecutive, i.e., double rate of the sorbent, has led to the decrease of $Z n_{\text {act }}$ fractions. The trends, when omitting the control, have developed most frequently a quadratic model. Such type of relationship enables assigning the optimal rate of sorbent $\left(D_{\text {opt }}\right)$, but simultaneously indicates that the excess of sorbent induces a secondary mobilization of the labile forms of $\mathrm{Zn}$, most frequently when exceeding $10 \mathrm{~g} \cdot \mathrm{kg}^{-1}$ soil. This phenomenon was observed earlier by Geebelen et al. [46] in the case of lead. 
The reported process emerged under conditions of treating the Zn-polluted soil with sorbents, where zeolite and bentonite differed in their share. The exception was observed with $Z B 50 / 50$, which induced a linear decrease of the $Z n_{a c t}$ fraction. The trends in the content of active $\mathrm{Zn}$ are in line with the investigations of Abad-Valle et al. [47], who significantly reduced the concentrations of water-soluble $\mathrm{Zn}, \mathrm{Cd}, \mathrm{Pb}$ after applying increasing rates of sepiolite.

The trends observed for the reactive zinc levels $\left(Z n_{\text {reac }}\right)$ were quite similar to those recorded for $Z n_{a c t}$, but the difference between the contents in the control and the soil treated with sorbents was very low. The decrease of $Z n_{\text {reac }}$ in the treatments with zeolite $(Z)$ at the first-rate, $2.5 \mathrm{~g} \cdot \mathrm{kg}^{-1}$ was $18-20 \%$, and for bentonite, much lower, i.e., $3-10 \%$. In the group of the blends, the highest reduction of $40-50 \%$ has been observed with $Z B 85 / 15$ (zeolite prevailed). This process was gradual with applying each consecutive rate, and the models generated with empirical data (including the control) were quadratic, enabling then calculating the optimal sorbent rate. In fact, lower sorbents rates, but inducing a much greater decrease of $Z n_{\text {reac }}$, has been observed in treatments with $Z B$, where zeolite (Z) predominated. Similar patterns were reported by Belviso et al. [48], who applied zeolite to a soil artificially polluted by zinc and lead. The stabilizing effect of zeolite with respect to reactive $\mathrm{Zn}$ forms in soil polluted with zinc was also outlined by Argiri and Tsadilas [49]. In a detailed study with eight different sorbents involving zeolite, bentonite and a phosphorus fertilizer, Fawzy [50] reported a much higher efficiency of zeolite over bentonite in stabilizing labile forms of copper and zinc. Motsi et al., [51] have tested the adsorption of some metals to zeolite and stated the highest chemical affinity of $\mathrm{Zn}^{2+}$ to zeolite as compared to $\mathrm{Cu}^{2+}$ or $\mathrm{Mn}^{2+}$, even.

The mobility of $\mathrm{Zn}$ expressed in terms of ionic activity has been much more considered as the parameter indicating with high probability its potential environmental fate [52]. The model reported in Section 3 "Evaluation of zinc activity-inactivation status" has integrated the key parameters (CEC, $p H$, ionic strength, total $\mathrm{Zn}$ content, $\mathrm{Zn}$ act and $\left.Z n_{\text {reac }}\right)$, which are the basis for validating the model. Mean activity data for zinc $(\gamma \mathrm{Zn})$ varied from around -11.5 to $-13.5 \mathrm{mmol} \cdot \mathrm{dm}^{-3}$ and is indicative of markedly low activity, irrespective of the type and rate of the particular sorbents. The proof of this status are the CEC values (Table 3), varying within the range $22.9-27.8 \mathrm{cmol}_{(+)} \cdot \mathrm{kg}^{-1}\left(\operatorname{control} C E C=15.2 \mathrm{cmol}_{(+)} \cdot \mathrm{kg}^{-1}\right)$ for the sorbent rates $2.5-20.0 \mathrm{~g} \cdot \mathrm{kg}^{-1}$. It means that about 2 CEC units were controlling 0.50 units of either $\gamma Z n_{\text {reac }}$ or $\gamma Z n_{a c t}$. Such ratio implies that zinc under current conditions of the inactivation process was potentially mobile (active). The incorporation of zeolite and bentonite, particularly the $Z B$ blends, significantly extended buffering capacities (CEC) to counteracting $\mathrm{Zn}$ lability. For the soil environment, this enhanced mitigating process hampers the emergence of Zn toxicity [2,53].

Soil reaction $(p H)$ appeared as the master parameter, which shaped the most the activities of both fractions, particularly the $Z n_{\text {reac }}$, with $\mathrm{R}^{2}=0.57$. It implies that about $60 \%$ of $\mathrm{Zn}$ reactions as induced by the incorporation of the sorbent were $\mathrm{pH}$-dependent. Sorbents, which shifted $\mathrm{pH}$ the most, were much more $\mathrm{pH}$-effective and concerned those with the highest share of bentonite $(B): Z B 15 / 85, Z B 30 / 70$ and ZB50/50. A similar pattern was observed for the $Z n_{a c t}$ pool, but $p H$ was less determinant of its activity. The evaluation made on the basis of criteria listed in Table 7 implies that in both cases, Zn activity was reduced, even at a $\mathrm{pH}$ of about 6.80 with $\gamma \mathrm{Zn}$ about $-11.5 \mathrm{mmol} \cdot \mathrm{dm}^{-3}$. This value was lower than the limit outlined as $-10.1 \mathrm{mmol} \cdot \mathrm{dm}^{-3}$. Data reported by Hough et al. [52] decidedly revealed that the parameter expressed as "Capacity = total metal content" is of low usefulness for explaining the mechanisms like those occurring in the current study. The model they tested, FIAM (Free Ion Activity Model) was based among others on metal activity "Intensity" in the soil solution. Hence, they concluded that $\mathrm{pH}$ could not be omitted in the process dealing with the ionic activity. Our study has shown that much more parameters should be considered at once for a reliable evaluation of inactivation goals. The use of mineral blends with significant sharing of zeolite is promising for the remediation of highly metal-polluted lands like in the case of zinc. 


\section{Conclusions and Statements}

(1) Incorporation of mineral sorbents like zeolite and bentonite as well as their blends led to a significant and permanent inactivation of about $22 \%$ of the labile forms of zinc in the soil.

(2) Blends with prevailing zeolite strongly inactivated the active zinc $\left(Z n_{a c t}\right)$ fractions just at the lowest rate $2.5 \mathrm{~g} \cdot \mathrm{kg}^{-1}$ soil. The sorbent $Z B 85 / 15 \mathrm{immobilized}$ about $66-71 \%$, as compared to zeolite (54\%) and bentonite (47\%).

(3) The content of the reactive zinc $\left(Z n_{\text {reac }}\right)$ fraction decreased much more when zeolite was incorporated $(20 \%)$ at the rate $2.5 \mathrm{~g} \cdot \mathrm{kg}^{-1}$ soil, with reference to bentonite $(10 \%)$ for the same rate. Blends exerted a high stabilizing effect with the highest, about $40-50 \%$ obtained for ZB85/15, i.e., with prevailing zeolite.

(4) The application of the sorbent $Z B 50 / 50$ enriched with triple superphosphate (TSP) raised the stabilization degree for both $\mathrm{Zn}$ fractions. The efficiency was significant at the TSP rate of $2.0 \%$ of the sorbent and at least the sorbent + TSP of $10 \mathrm{~g} \cdot \mathrm{kg}^{-1}$ soil.

(5) Low levels of $Z n_{a c t}$, as well as $Z n_{\text {reac }}$, resulted in the occurrence of strong buffering conditions $(C E C)$ of the soils induced by the sorbents. About 2 CEC units were controlling 0.50 units of either $\gamma Z n_{\text {reac }}$ or $\gamma Z n_{a c t}$, hence a very low zinc ionic activity.

(6) The use of mineral blends with higher sharing of zeolite is promising for efficient remediation of metal-polluted lands in the case of zinc.

Author Contributions: Conceptualization, J.D. and A.A.; methodology, J.D.; validation, J.D., W.G. and A.A.; formal analysis, J.D.; investigation, A.A.; resources, L.D.; data curation, J.D., W.G. and L.D.; writing—original draft preparation, J.D. and A.A.; writing—review and editing, J.D., W.G., and Z.K.; visualization, A.A., W.G. and L.D., supervision, J.D. and Z.K.; funding acquisition, J.D. and Z.K. All authors have read and agreed to the published version of the manuscript.

Funding: Publication was co-financed within the framework of the Polish Ministry of Science and Higher Education's program: "Regional Initiative Excellence" in the years 2019-2022 (No. 005/RID/2018/19).

Data Availability Statement: No data availability was provided with the paper.

Conflicts of Interest: The authors declare no conflict of interest.

\section{References}

1. US EPA. Use of Monitored Natural Attenuation at Superfund, RCRA Corrective Action and Underground Storage Tank Sites; OSWER Directive Number 9200.4-17P; Office of Solid Waste and Emergency Response: Washington, DC, USA, 1999.

2. Mulligan, C.N.; Yong, R.N. Natural attenuation of contaminated soils. Environ. Int. 2004, 30, 587-601. [CrossRef] [PubMed]

3. Bradshaw, A. The use of natural processes in reclamation-Advantages and difficulties. Landsc. Urban Plan. 2000, 51, 89-100. [CrossRef]

4. Boros-Lajszner, E.; Wyszkowska, J.; Kucharski, J. Use of a zeolite and molecular sieve to restore homeostasis of soil contaminated with cobalt. Minerals 2020, 10, 53. [CrossRef]

5. Daiwen, Z. Research on remediation methods of contaminated land and development trend. Environ. Resour. Ecol. J. 2018, 2, 15-21. [CrossRef]

6. Zuzana, S.; Katarína, D.; Lívia, T. Biodegradation and ecotoxicity of soil contaminated by pentachlorophenol applying bioaugmentation and addition of sorbents. World J. Microbiol. Biotechnol. 2009, 25, 243-252. [CrossRef]

7. Kumpiene, J. Trace Elements Immobilization in Soil Using Amendments. Trace Elements in Soils; Wiley-Blackwell Publishing Inc.: Chichester, UK, 2010; pp. 353-379. [CrossRef]

8. Rhodes, C.J. Properties and applications of zeolites. Sci. Prog. 2010, 93, 223-284. [CrossRef] [PubMed]

9. Blisset, R.S.; Rowson, N.A. A review of the multi-component utilisation of coal fly ash. Fuel 2012, 97, 1-23. [CrossRef]

10. Ouki, S.K.; Kavannagh, M. Performance of natural zeolites for the treatment of mixed metal-contaminated effluents. Water Manag. Res. 1997, 15, 383-394. [CrossRef]

11. Ghobarkar, H.; Schäf, O.; Guth, U. Zeolites-From kitchen to space. Prog. Solid State Chem. 1999, 27, 29-73. [CrossRef]

12. Panuccio, M.R.; Sorgona, A.; Rizzo, M.; Cacco, G. Cadmium adsorption on vermiculite, zeolite and pumice: Batch experimental studies. J. Environ. Manag. 2009, 90, 364-374. [CrossRef]

13. Terzano, R.; Spagnuolo, M. Heavy Metal Stabilization by Promoting Zeolite Synthesis in Soil. In Detoxification of Heavy Metals; Soil Biology; Sherameti, I., Varma, A., Eds.; Springer: Berlin/Heidelberg, Germany, 2011; Volume 30, pp. 423-438. [CrossRef] 
14. Faheem, U. Montmorillonite: An introduction to properties and utilization. In Current Topics in the Utilization of Clay in Industrial and Medical Applications; Zoveidavianpoor, M., Ed.; IntechOpen: London, UK, 2018. [CrossRef]

15. Jelinek, P. Pojivové Soustavy Slévárenských Formovacích Směsí; Vlastní náklad; Technická Univerzita Ostrava: Ostrava, Czech Republic, 2004; p. 241, ISBN 80-239-2188-6.

16. García-Romero, E.; Manchado, E.M.; Suárez, M.; García-Rivas, J. Spanish Bentonites: A review and new data on their geology, mineralogy, and crystal chemistry. Minerals 2019, 9, 696. [CrossRef]

17. Kai, Y.; Jian, X.; Xiaohong, J.; Cun, L.; Wesley, M.C.; Jinlong, L. Stabilization of heavy metals in soil using two organo-bentonites. Chemosphere 2017, 184, 884-891. [CrossRef]

18. Alkorta, I.; Becerril, J.M.; Garbisu, C. Phytostabilization of metal contaminated soils. Rev. Environ. Health 2010, 25, 135-146. [CrossRef]

19. Brümmer, G.W.; Gerth, J.; Herms, U. Heavy metals species, mobility and availability in soils. Z. Pflanzenernähr. Bodenkd 1986, 149, 382-389. [CrossRef]

20. Chrysochoou, M.; Dermatas, D.; Grubb, D.G. Phosphate application to firing range soils for Pb immobilization: The unclear role of phosphate. J. Hazard. Mater. 2007, 144, 1-14. [CrossRef]

21. Cao, X.; Ma, L.Q.; Singh, S.P.; Zhou, Q. Phosphate-induced lead immobilization from different lead minerals in soil under varying pH conditions. Environ. Pollut. 2008, 152, 184-192. [CrossRef]

22. Corami, A.; Mignardi, S.; Ferrini, V. Copper and zinc decontamination from single- and binary-metal solution using hydroxyapatite. J. Hazard. Mater. 2007, 146, 164-170. [CrossRef]

23. Gupta, D.K.; Chatterjee, S.; Datta, S.; Veer, V.; Walther, C. Role of phosphate fertilizers in heavy metal uptake and detoxification of toxic metals. Chemosphere 2014, 108, 134-144. [CrossRef]

24. Sutherland, R.A.; Tack, F.M.G. Determination of $\mathrm{Al}, \mathrm{Cu}, \mathrm{Fe}, \mathrm{Mn}, \mathrm{Pb}$ and $\mathrm{Zn}$ in certified reference materials using the optimized BCR sequential extraction procedure. Anal. Chim. Acta 2002, 454, 249-257. [CrossRef]

25. Soil Survey Staff. Soil Survey Field and Laboratory Methods Manual; Soil Survey Investigations Report No. 51, Version 2.0; Burt, R., Soil Survey Staff, Eds.; Natural Resources Conservation Service, U.S. Department of Agriculture: Washington, DC, USA, 2014.

26. European Standard-EN 15933 Sludge, Treated Biowaste and Soil-Determination of pH. 2012. Available online: https:// standards.iteh.ai/catalog/standards/cen/e24123eb-a06b-427b-bed5-f5ad65d437e8/en-15933-2012 (accessed on 5 June 2021).

27. Wang, X.; Wang, J.; Zhang, J. Comparisons of three methods for organic and inorganic carbon in calcareous soils of Northwestern China. PLoS ONE 2012, 7, e44334. [CrossRef]

28. Hazelton, P.; Murphy, B. Interpreting Soil Test Results. What Do All the Numbers Mean? CSIRO Publishing: Clayton, VIC, Australia, 2016; p. 200, ISBN 9781486303960.

29. Carter, D.L.; Mortland, M.M.; Kemper, W.D. Specific surface. In Methods of Soils Analysis, Part I—Physical and Mineralogical Methods, 2nd ed.; Klute, A., Ed.; American Society of Agronomy: Madison, WI, USA, 1986; pp. 413-423.

30. De Jong, E. Comparison of three methods of measuring surface area of soils. Can. J. Soil Sci. 1999, 79, 345-351. [CrossRef]

31. Lebourg, A.; Sterckemen, T.; Ciesielski, H.; Priox, N. Intérét de différents réactif d'extraction chimique pour l'évaluation de la disponibilité des métaux en traces du sol. Agron. Agric. Environ. 1996, 16, 201-215.

32. Gupta, S.K.; Vollmer, M.K.; Krebs, R. The importance of mobile, mobilisable and pseudo total heavy metal fractions in soil of three-level risk assessment and risk management. Sci. Total Environ. 1996, 178, 11-20. [CrossRef]

33. Gregg, S.J.; Sing, K.S.W. Adsorption, Surface Area and Porosity; Academic Press Inc.: London, UK, $1967 ;$ pp. 44-50.

34. Sparks, D.L. Environmental Soil Chemistry, 2nd ed.; Academic Press Inc.: San Diego, CA, USA, 2003; p. 267, ISBN 9780126564464. [CrossRef]

35. Jandy, M. Ocena Biogeochemicznych Przemian Zn, Cu, Pb, Cd w Parku im Karola Marcinkowskiego Oraz w Rekreacyjnym Parku Sołackim w Poznaniu. Master's Thesis, University of Life Sciences in Poznań, Poznań, Poland, $2009 ;$ p. 101.

36. Singh, A.; Agrawal, M.; Marshall, F.M. The role of organic vs. inorganic fertilizers in reducing phytoavailability of heavy metals in a wastewater-irrigated area. Ecol. Eng. 2010, 36, 1733-1740. [CrossRef]

37. Tica, D.; Udovic, M.; Lestan, D. Immobilization of potentially toxic metals Using different soil amendments. Chemosphere 2011, 85, 577-583. [CrossRef]

38. Xu, Y.; Liang, X.; Xu, Y.; Qin, X.; Huang, Q.; Wang, L.; Sun, Y. Remediation of Heavy Metal-Polluted Agricultural Soils Using Clay Minerals: A Review. Pedosphere 2017, 27, 193-204. [CrossRef]

39. Lee, J.H.; Ahn, B.K. Comparisons of Various Chemical Extracts as Quantity Factors to Determine Metal-Buffering Capacity of Soils. Commun. Soil Sci. Plant Anal. 2010, 41, 1463-1477. [CrossRef]

40. Lin, C.F.; Lo, S.S.; Lin, H.Y.; Lee, Y. Stabilization of cadmium contaminated soils using synthesized zeolite. J. Hazard. Mater. 1998, 60, 217-226. [CrossRef]

41. Shi, W.; Shao, H.; Li, H.; Shao, M.; Du, S. Progress in the remediation of hazardous heavy metal-polluted soils by natural zeolite. J. Hazard. Mater. 2009, 170, 1-6. [CrossRef]

42. Diatta, J.B.; Kociałkowski, W. Adsorption of zinc in some selected soils. Pol. J. Environ. Stud. 1998, 7, $195-200$.

43. Sanders, J.R.; Adams, T.M. The effects of $\mathrm{pH}$ and soil type on concentrations of zinc, copper and nickel extracted by calcium chloride from sewage sludge-treated soils. Environ. Pollut. 1987, 43, 219-228. [CrossRef]

44. Agbenin, J.O.; Olojo, L.A. Competitive adsorption of copper and zinc by a Bt horizon of a savanna Alfisol as affected by $\mathrm{pH}$ and selective removal of hydrous oxides and organic matter. Geoderma 2004, 119, 85-95. [CrossRef] 
45. Radziemska, M.; Mazur, Z. Content of selected heavy metals in contaminated soil following the application of halloysite and zeolite. J. Ecol. Eng. 2016, 17, 125-133. [CrossRef]

46. Geebelen, W.; Vangronsveld, J.; Adriano, D.C.; Carleer, R.; Clijsters, H. Amendment-induced immobilization of lead in lead-spiked soil. Evidence from phytotoxicity studies. Water Air Soil Pollut. 2002, 140, 261-277. [CrossRef]

47. Abad-Valle, P.; Alvarez-Ayuso, E.; Murciego, A.; Pellitero, E. Assessment of the use of sepiolite amendment to restore heavy metal polluted mine soil. Geoderma 2016, 280, 57-66. [CrossRef]

48. Belviso, C.; Cavalcante, F.; Ragone, P.; Fiore, S. Immobilization of $\mathrm{Zn}$ and $\mathrm{Pb}$ in polluted soil by in situ crystallization zeolites from fly ash. Water Air Soil Pollut. 2012, 223, 5357-5364. [CrossRef]

49. Argiri, A.G.; Tsadilas, C.D. Bioaccumulation of Heavy Metals from Soil into Alfalfa. Res. J. Pharm. Biol. Chem. Sci. 2016, 7, 2981-2989.

50. Fawzy, E.M. Soil remediation using in situ immobilisation techniques. Chem. Ecol. 2008, 24, 147-156. [CrossRef]

51. Motsi, T.; Rowson, N.A.; Simmons, M.J.H. Adsorption of heavy metals from acid mine drainage by natural zeolite. Int. J. Miner. Process. 2009, 92, 42-48. [CrossRef]

52. Hough, R.L.; Tye, A.M.; Crout, N.M.J.; McGrath, S.P.; Zhang, H.; Young, S.D. Evaluating a 'Free Ion Activity Model' applied to metal uptake by Lolium perenne L. grown in contaminated soils. Plant Soil. 2005, 270, 1-12. [CrossRef]

53. Draszawka-Bołzan, B. Effect of pH and soil environment. World News Nat. Sci. 2017, 8, 50-60. 